Keywords: SB7, sludge

washing, sludge settling

Retention: Permanent

\title{
Sludge Batch 7 (SB7) Washing Demonstration to Determine Sulfate/Oxalate Removal Efficiency and Settling Behavior
}

\author{
S. H. Reboul \\ D. R. Click \\ D. P. Lambert
}

December 2010

Savannah River National Laboratory Savannah River Nuclear Solutions Aiken, SC 29808

Prepared for the U.S. Department of Energy under contract number DE-AC09-08SR22470.

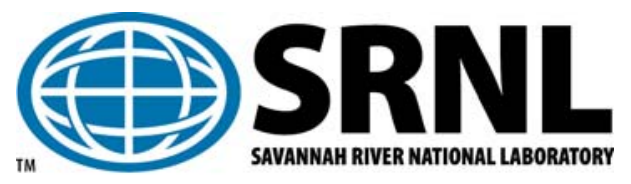




\section{DISCLAIMER}

This work was prepared under an agreement with and funded by the U.S. Government. Neither the U.S. Government or its employees, nor any of its contractors, subcontractors or their employees, makes any express or implied:

1. warranty or assumes any legal liability for the accuracy, completeness, or for the use or results of such use of any information, product, or process disclosed; or

2. representation that such use or results of such use would not infringe privately owned rights; or

3. endorsement or recommendation of any specifically identified commercial product, process, or service.

Any views and opinions of authors expressed in this work do not necessarily state or reflect those of the United States Government, or its contractors, or subcontractors.

\section{Printed in the United States of America}

Prepared for U.S. Department of Energy 


\section{REVIEWS AND APPROVALS}

\section{AUTHORS:}

S. H. Reboul, Process Technology Programs

Date

D. R. Click, Analytical Development

Date

D. P. Lambert, Process Technology Programs

Date

TECHNICAL REVIEW:

J. M. Pareizs, Process Technology Programs

Date

APPROVAL:

C. C. Herman, Manager

Date

Process Technology Programs

S. L. Marra, Manager

Date

Environmental \& Chemical Process Technology Research Programs

M. T. Keefer, Manager

Date

Savannah River Remediation Engineering 


\section{ACKNOWLEDGEMENTS}

The following individuals are acknowledged for contributing to this study: Lucy Beasley, Debbie Burckhalter, Mona Galloway, Jane Howard, Monica Jenkins, Jeff Mixon, Rita Sullivan, and Dee Wheeler, who performed the sample preparations and Shielded Cell sample measurements; Curtis Johnson, who performed the CVAA analyses; Mark Jones, who performed the ICP-AES analyses; Kathy White, who performed the base titration and TIC/TOC analyses; and Boyd Wiedenman, who performed the IC analyses. The assistance of each of these individuals is appreciated. 


\section{EXECUTIVE SUMMARY}

To support Sludge Batch 7 (SB7) washing, a demonstration of the proposed Tank Farm washing operation was performed utilizing a real-waste test slurry generated from Tank 4, 7 , and 12 samples. The purpose of the demonstration was twofold: 1) to determine the settling time requirements and washing strategy needed to bring the SB7 slurry to the desired endpoint; and 2) to determine the impact of washing on the chemical and physical characteristics of the sludge, particularly those of sulfur content, oxalate content, and rheology.

Seven wash cycles were conducted over a four month period to reduce the supernatant sodium concentration to approximately one molar. The long washing duration was due to the slow settling of the sludge and the limited compaction. Approximately $90 \%$ of the sulfur was removed through washing, and the vast majority of the sulfur was determined to be soluble from the start. In contrast, only about half of the oxalate was removed through washing, as most of the oxalate was initially insoluble and did not partition to the liquid phase until the latter washes. The final sulfur concentration was $0.45 \mathrm{wt} \%$ of the total solids, and the final oxalate concentration was $9,900 \mathrm{mg} / \mathrm{kg}$ slurry. More oxalate could have been removed through additional washing, although the washing would have reduced the supernatant sodium concentration.

The yield stress of the final washed sludge (35 Pa) was an order of magnitude higher than that of the unwashed sludge ( $\sim \mathrm{Pa})$ and was deemed potentially problematic. The high yield stress was related to the significant increase in insoluble solids that occurred $(\sim 8$ $\mathrm{wt} \%$ to $\sim 18 \mathrm{wt} \%$ ) as soluble solids and water were removed from the slurry. Reduction of the insoluble solids concentration to $\sim 14 \mathrm{wt} \%$ was needed to reduce the yield stress to an acceptable level. However, depending on the manner that the insoluble solids adjustment was performed, the final sodium concentration and extent of oxalate removal would be prone to change. As such, the strategy for completing the final wash cycle is integral to maintaining the proper balance of chemical and physical requirements. 


\section{TABLE OF CONTENTS}

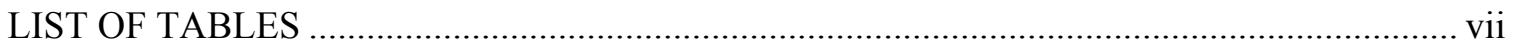

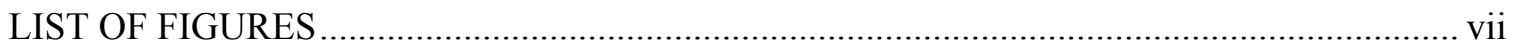

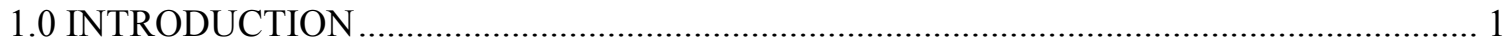

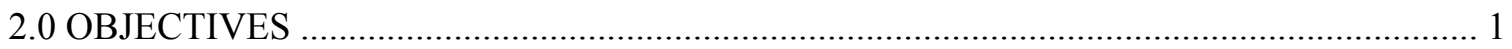

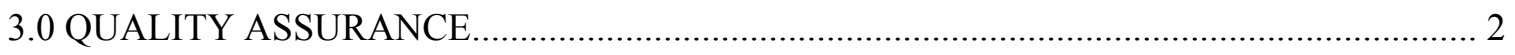

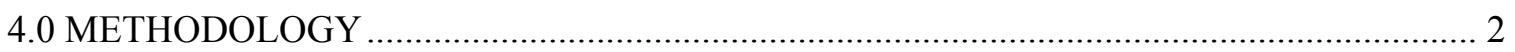

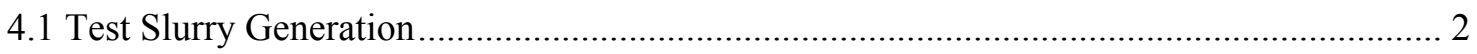

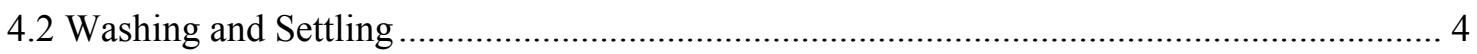

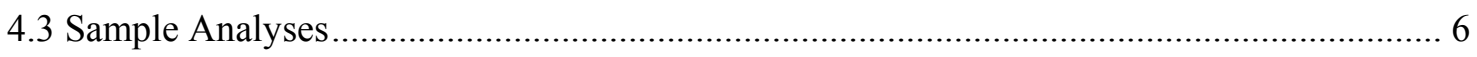

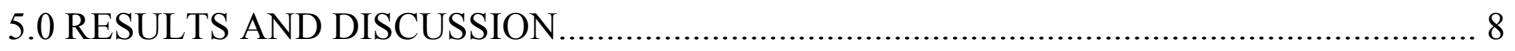

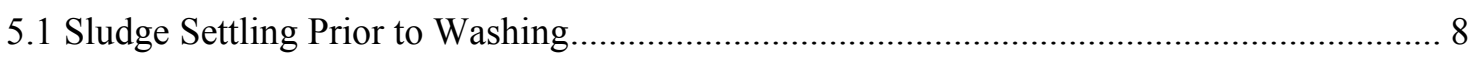

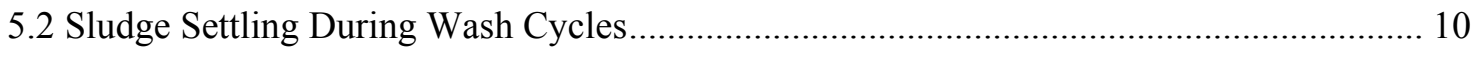

5.3 Characterization of Supernatants from the Various Wash Cycles .................................... 11

5.4 Physical Properties of Unwashed and Washed Sludge................................................... 14

5.5 Chemical Composition of Unwashed and Washed Sludge.............................................. 16

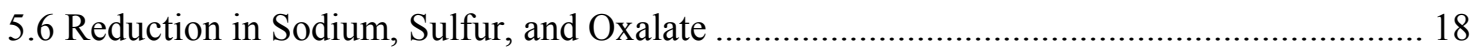

5.7 Balancing Physical and Chemical Requirements ......................................................... 19

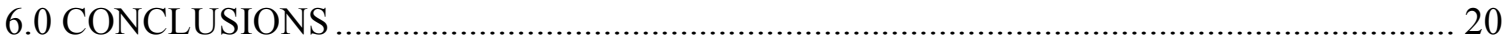

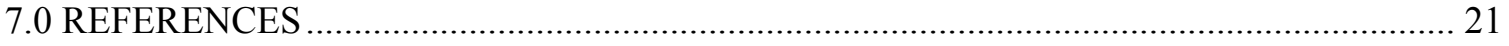

APPENDIX A: FLOW CURVES FROM RHEOLOGY MEASUREMENTS ........................... 23 


\section{LIST OF TABLES}

Table 4-1. SRR Projections of the Distribution of Insoluble Solids............................................. 2

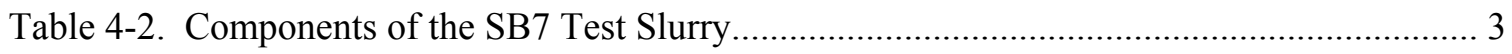

Table 4-3. Composition of the Supernatant Simulant ................................................................ 3

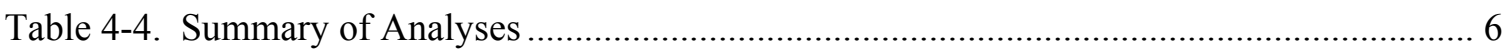

Table 5-1. Sludge Settling Prior to Washing (2-L Vessel) …..................................................... 9

Table 5-2. Sludge Settling During the Wash Cycles (1-L Vessel) .............................................. 10

Table 5-3. Supernatant Constituent Concentrations as a Function of Wash Cycle ...................... 12

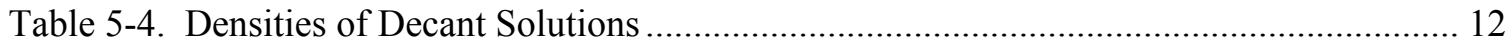

Table 5-5. Physical Properties of Unwashed and Washed Sludge .............................................. 14

Table 5-6. Rheological Properties as a Function of Insoluble Solids Content ............................. 15

Table 5-7. Elemental Constituent Concentrations in Unwashed and Washed Sludge ................. 17

Table 5-8. Oxalate Concentrations of Unwashed and Washed Slurries ...................................... 17

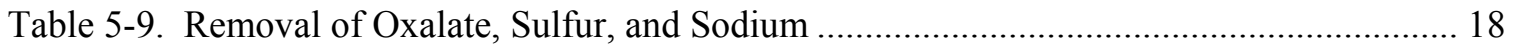

\section{LIST OF FIGURES}

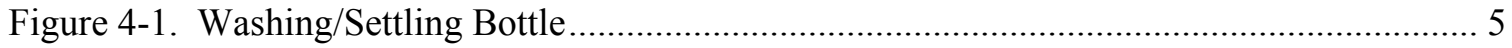

Figure 5-1. Settled Sludge Height as a Function of Time (Prior to Washing) ............................. 9

Figure 5-2. Settled Sludge Heights as Functions of Time and Wash Cycle................................. 11

Figure 5-3. Supernatant Constituent Concentrations Plotted Versus Wash Cycle ....................... 14

Figure 5-4. Yield Stress as a Function of Insoluble Solids Content ............................................ 15

Figure 5-5. Consistency as a Function of Insoluble Solids Content........................................... 16 


\section{LIST OF ABBREVIATIONS}

$\begin{array}{ll}\text { SB7 } & \text { Sludge Batch 7 } \\ \text { DWPF } & \text { Defense Waste Processing Facility } \\ \text { CPC } & \text { Chemical Processing Cell } \\ \text { HM } & \text { H-Modified } \\ \text { SRR } & \text { Savannah River Remediation } \\ \text { TTQAP } & \text { Task Technical and Quality Assurance Plan } \\ \text { IS } & \text { Insoluble solids } \\ \mathrm{Na}_{2} \mathrm{C}_{2} \mathrm{O}_{4} & \text { Sodium oxalate } \\ \text { ICP-AES } & \text { Inductively Coupled Plasma-Atomic Emission Spectroscopy } \\ \text { IC } & \text { Ion chromatography } \\ \text { CVAA } & \text { Cold vapor atomic absorption } \\ \text { TIC } & \text { Total inorganic carbon } \\ \text { TS } & \text { Total solids }\end{array}$




\subsection{INTRODUCTION}

The primary contributors to Sludge Batch 7 (SB7) are wastes from Tanks 4, 7, and 12. Each of these wastes has characteristics that can impede processing due to inherent chemical and/or physical properties.

Tank 4 sludge has a high sulfur content ${ }^{1}$ due to the ferrous sulfamate added in the FCanyon separation process. High concentrations of sulfur can interfere with glass production at the Defense Waste Processing Facility (DWPF). Tank 7 sludge has a high oxalate content ${ }^{2}$ due to oxalic acid inputs associated with cleaning of Tanks 5 and 6. High oxalate concentrations can complicate acidification and redox adjustment in the DWPF Chemical Processing Cell (CPC), and can raise the solubility of iron, reducing the amount in the solid phase serving as a neutron poison. Tank 12 sludge is an H-modified (HM) waste and therefore contains high concentrations of aluminum. ${ }^{1,3}$ High aluminum waste typically settles very slowly during sludge washing and has rheological properties that can prevent efficient pumping during transfers.

Because of the potential processing problems associated with each of the SB7 components, a real-waste laboratory washing demonstration was performed. The demonstration was performed on a one-liter test slurry generated using sludge samples taken from Tanks 4, 7, and 12. The demonstration addressed two principal concerns: 1) the settling time requirements and washing strategy necessary to bring the SB7 waste to the desired endpoint; and 2) the impact that sludge washing would have on the physical properties and the chemical composition of the SB7 waste (including changes in the waste rheology and in the quantities of interfering constituents).

This study was performed at the request of the Engineering Department of Savannah River Remediation (SRR). ${ }^{4}$

\subsection{OBJECTIVES}

The overall goal of the demonstration was to obtain sufficient data to get an early indication of the key chemical and physical properties of the SB7 waste during the sludge washing process. The specific objectives were:

1) Quantify the sludge settling behavior as a function of the wash cycles;

2) Determine the amount of washing needed to reduce the sodium concentration to the desired endpoint;

3) Identify the physical and chemical properties of the washed and unwashed sludge; and

4) Determine the effectiveness of washing on sulfur and oxalate removal. 


\subsection{QUALITY ASSURANCE}

This study was conducted in accordance with the quality assurance protocols identified in the Task Technical and Quality Assurance Plan (TTQAP). ${ }^{5}$ All of the raw data and ancillary information related to this study have been recorded in laboratory notebooks SRNL-NB-2010-00052 ${ }^{6}$ and SRNL-NB-2010-00125. ${ }^{7}$

\subsection{METHODOLOGY}

\subsection{Test Slurry Generation}

The SB7 test slurry was generated by combining aliquots of previously-collected Tank 12, 7 , and 4 sludge samples. The targeted blend ratio was that of SRR's SB7 projections, as identified in the SB6-7 planning spreadsheet. ${ }^{8}$ A summary of the insoluble solids (IS) distribution is shown in Table 4-1. Note that: a) this distribution of insoluble solids was projected based on a total of five sludge transfers from Tanks 12, 7, and 4 (transfers 12$51 \mathrm{~A}, 7-51 \mathrm{~A}$, etc.); and b) the contribution of the SB6 heel insolubles was neglected due to its small mass $(7945 \mathrm{~kg})$ relative to the masses of the other insoluble solids.

Table 4-1. SRR Projections of the Distribution of Insoluble Solids

\begin{tabular}{|l|c|c|c|c|c|}
\hline \multirow{2}{*}{$\begin{array}{l}\text { Transfer } \\
\text { Identifier }\end{array}$} & \multicolumn{5}{|c|}{ Insoluble Solids Projected in the SRR Plan, kg* } \\
\cline { 2 - 6 } & $\begin{array}{c}\text { Tank 12 } \\
\text { Sludge }\end{array}$ & $\begin{array}{c}\text { Tank 7 } \\
\text { Sludge }\end{array}$ & $\begin{array}{c}\text { Tank 7 } \\
\mathrm{Na}_{2} \mathrm{C}_{2} \mathrm{O}_{4}\end{array}$ & $\begin{array}{c}\text { Tank 4 } \\
\text { Sludge }\end{array}$ & $\begin{array}{c}\text { Sum of Sludge } \\
\text { and } \mathrm{Na}_{2} \mathrm{C}_{2} \mathrm{O}_{4}\end{array}$ \\
\hline \hline 12-51A & 80,000 & & & & 80,000 \\
\hline 7-51A & & 100,152 & 49,203 & & 149,355 \\
\hline 12-51B & 41,832 & & & & 41,832 \\
\hline 7-51B & & 2185 & 0 & & 2185 \\
\hline 4-51 & & & & 40,000 & 40,000 \\
\hline Total & 121,832 & 102,337 & 49,203 & 40,000 & 313,372 \\
\hline Fraction & $39 \%$ & $33 \%$ & $16 \%$ & $13 \%$ & $100 \%$ \\
\hline \multicolumn{7}{|l|}{ *The SB6 heel (7945 kg IS) was neglected due to its small relative contribution. }
\end{tabular}

As shown in the table, the total projected mass of insoluble solids is $\sim 310,000 \mathrm{~kg}$ and the fractions associated with Tanks 12, 7, and 4 sludges are $39 \%, 33 \%$, and $13 \%$, respectively. The remaining $16 \%$ is solid phase sodium oxalate $\left(\mathrm{Na}_{2} \mathrm{C}_{2} \mathrm{O}_{4}\right)$ associated with tank cleaning solutions received into Tank 7.

Per SRR's plan, the total projected sludge volume will be $6.8 \mathrm{E}+5$ gallons. ${ }^{8}$ This volume coupled with the projected insoluble solids mass yields an insoluble solids concentration of approximately $120 \mathrm{~g} / \mathrm{L}$.

In order to generate a sufficient quantity of test slurry to have one-liter available for washing and $0.3 \mathrm{~L}$ available for characterization, a total insoluble solids content of $\sim 150$ $\mathrm{g}$ was targeted $(1.3 \mathrm{~L} \mathrm{x} 120 \mathrm{~g} / \mathrm{L})$. The breakdown of components utilized to generate the 
test slurry is identified in Table 4-2. As shown in the table, the fractions of insoluble solids contributed by the sources were: $38 \%$ for the Tank 12 sample; $31 \%$ for the Tank 7 sample; $15 \%$ for the sodium oxalate; and $16 \%$ for the Tank 4 sample. The differences between these fractions and the targeted fractions (Table 4-1) are considered modest.

Table 4-2. Components of the SB7 Test Slurry

\begin{tabular}{|l|c|c|c|c|}
\hline Parameter & $\begin{array}{c}\text { Tank 12 } \\
\text { Sample }\end{array}$ & $\begin{array}{c}\text { Tank 7 } \\
\text { Sample (Washed)* }\end{array}$ & $\mathrm{Na}_{2} \mathrm{C}_{2} \mathrm{O}_{4}$ & $\begin{array}{c}\text { Tank 4 } \\
\text { Sample }\end{array}$ \\
\hline \hline Slurry mass, g & 769 & 613 & 22.9 & 662 \\
\hline IS content, wt $\%$ & 7.5 & 7.8 & $\sim 100$ & 3.6 \\
\hline IS mass, g & 57.7 & 47.8 & $\sim 22.9$ & 23.8 \\
\hline IS fraction, \% & 38 & 31 & 15 & 16 \\
\hline
\end{tabular}

* The sodium oxalate content of the Tank 7 sample was considered negligible, since the sample had been washed excessively in a previous laboratory demonstration.

The specifics of the test slurry generation process were:

A. $769 \mathrm{~g}$ of the Tank 12 sludge was mixed with $613 \mathrm{~g}$ of the Tank 7 sludge (washed) in a 2-L volume-calibrated polypropylene bottle.

B. $819 \mathrm{~g}$ of supernatant simulant and $22.9 \mathrm{~g}$ of sodium oxalate were mixed into the slurry. (Note that $819 \mathrm{~g}$ was the most simulant that could be added without exceeding the practical capacity of the bottle). The simulant was introduced for the purpose of adding back soluble constituents that were removed when the Tank 7 material was washed. The primary objective was to adjust the chemistry: a) such that the supernatant composition was similar to that of SRR's Tank 12/Tank 7 blend projection; and b) to ensure that the sodium concentration was high enough that the added sodium oxalate would remain insoluble. The composition of the supernatant simulant is given in Table 4-3.

C. The insoluble solids were allowed to settle for a 13 day period. (The settling rate had dropped considerably by the thirteenth day).

D. $954 \mathrm{~g}$ of supernatant was decanted (removed) from the slurry.

E. $662 \mathrm{~g}$ of the Tank 4 sludge was mixed with the slurry, and then a $412 \mathrm{~g}$ aliquot of the mixed slurry ( $\sim 300 \mathrm{~mL}$ of slurry) was removed for characterization.

Table 4-3. Composition of the Supernatant Simulant

\begin{tabular}{|l|c|}
\hline Constituent & Molarity \\
\hline \hline Sodium nitrite & 0.56 \\
\hline Sodium nitrate & 0.57 \\
\hline Sodium hydroxide & 1.1 \\
\hline Sodium sulfate & 0.06 \\
\hline Sodium carbonate & 0.15 \\
\hline Sodium aluminate & 0.12 \\
\hline
\end{tabular}




\subsection{Washing and Settling}

After removing the aliquot for characterization, $1520 \mathrm{~g}(1.2 \mathrm{~L})$ of the unwashed slurry remained in the $2-\mathrm{L}$ volume-calibrated vessel. This material was allowed to settle for a period of 14 days. During this period, settled sludge heights were recorded each workday. At the end of the settling period, $434 \mathrm{~g}$ of supernatant was decanted, leaving $1086 \mathrm{~g}$ of material. This material was subsequently mixed, and then a $128 \mathrm{~g}$ aliquot $(\sim 100 \mathrm{~mL})$ was removed for rheology measurements. The mass of remaining material was $958 \mathrm{~g}$, with a volume of approximately $0.75 \mathrm{~L}$.

A total of seven washes were performed on the slurry. In all but the second wash, inhibited water was used as the washing solution. (The inhibited water contained 0.011 $\mathrm{M}$ sodium nitrite and $0.010 \mathrm{M}$ sodium hydroxide). In the second wash, a solution of inhibited water mixed with additional sodium nitrite was utilized. (This wash solution contained 1.29 $\mathrm{M}$ sodium nitrite and $0.008 \mathrm{M}$ sodium hydroxide). The additional sodium nitrite was used to balance the nitrite to nitrate ratio, for inhibition of tank corrosion.

The quantities of wash solution that were added to the slurry were chosen to emulate a tank fill height of 198 inches (corresponding to a tank volume of 695,000 gallons) under the initial conditions of 9.8 weight percent insoluble solids. Correspondingly, the amount of supernatant decanted at the end of each wash cycle was chosen to target an "after decant" tank slurry height of 147 inches (corresponding to a tank volume of 516,000 gallons).

Based on the initial targeted insoluble solids content (9.8 weight percent), the mass of the first wash solution added to the decanted slurry was $113 \mathrm{~g}$. This brought the total mass of slurry and wash solution to $1071 \mathrm{~g}$. Following addition of the wash solution, the slurry/wash solution combination was mixed for 5 minutes via continuous inversion, shaking, and rolling of the 2-L slurry bottle. After mixing, the volume of the combined slurry was $\sim 0.87 \mathrm{~L}$.

To facilitate tracking of sludge settling, the slurry was then transferred from the 2-L calibrated bottle to a 1-L calibrated bottle (use of a smaller bottle improved the ability to discern changes in the settled sludge height). In transferring the material, $30 \mathrm{~g}$ of slurry material was retained on the walls of the original 2-L bottle. Consequently, the total mass of material moved to the 1-L bottle was $1041 \mathrm{~g}$.

In terms of the original undecanted test slurry, the reduction in mass due to removal of material for rheology measurements and loss of material during transfer was quantified by the following factor:

$$
(958 \mathrm{~g} \div 1086 \mathrm{~g}) \times(1041 \mathrm{~g} \div 1071 \mathrm{~g})=0.857
$$

Therefore, the equivalent mass of original slurry that was represented in the sludge moved into the 1-L bottle was $1303 \mathrm{~g}$ (1520 $\mathrm{g} \mathrm{x} \mathrm{0.857).} \mathrm{This} \mathrm{is} \mathrm{the} \mathrm{mass} \mathrm{that} \mathrm{was} \mathrm{utilized}$ in determining "pre-wash" quantities of constituents such as sodium, sulfur, and oxalate. 
A photograph of the 1-L bottle utilized for tracking sludge settling during the wash cycles is given in Figure 4-1. Note that this photograph was taken outside of the Shielded Cells, for illustration purposes, utilizing a sludge simulant. As such, the appearance of the supernatant and sludge phases as seen in the photo should not be considered reflective of the real waste. In actuality, the real-waste supernatant phase contained significantly less color than the supernatant shown in the figure.

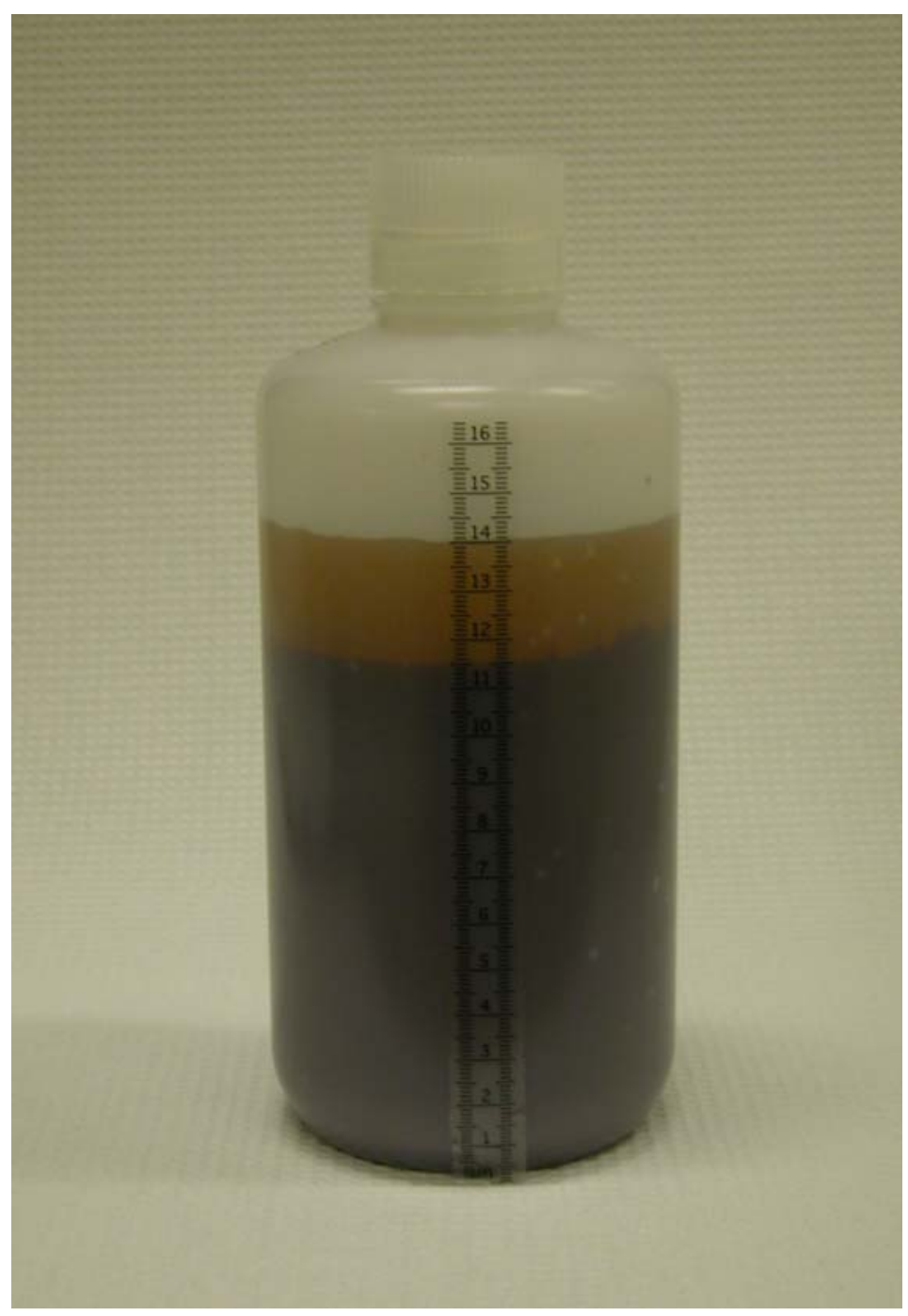

Figure 4-1. Washing/Settling Bottle

As shown in the figure, the bottle is equipped with graduations that facilitate tracking of total slurry height and settled sludge height. Numbers identified by the large graduation marks indicate height by units of centimeters.

In the 1-L bottle, the height of the test slurry containing the wash solution (9.8 weight percent insoluble solids) was 13.9 centimeters and corresponded to SRR's planned tank 
fill height of 198 inches. Based on the ratio of SRR's planned 'after decant tank slurry height" (147 inches) to SRR's planned tank fill height (198 inches), $10.3 \mathrm{~cm}$ was the nominal "after decant" height target for the test slurry. This nominal height target applied to the first six washes. However, following the seventh wash cycle, the "after decant" slurry height was targeted to be as low as practical.

The first six wash cycles were performed in accordance with the following steps:

1. Sufficient wash solution was added to the slurry to bring its height to $13.9 \mathrm{~cm}$.

2. The slurry/wash solution combination was mixed for 5 minutes, via continuous inversion, shaking, and rolling of the "washing" bottle.

3. The sludge was allowed to settle undisturbed for a period of time until the settling rate dropped to a level where additional settling was impractical. (The settling periods ranged from 7 to 14 days). During these periods, the settled sludge heights were recorded each weekday morning (typically at 7:30 a.m.).

4. Following each settling period, free supernatant was decanted from the top of the slurry, via pumping. The goal was to remove the maximum amount of free supernatant without disturbing the settled sludge.

The seventh wash cycle was performed in accordance with the steps above - however, after Step 4 was completed, Steps 2 to 4 were repeated to concentrate the sludge further. The settling period for concentrating the sludge was 16 days.

Following the final decant, the mass of the washed, concentrated slurry was $650 \mathrm{~g}$. The corresponding volume was $0.53 \mathrm{~L}$.

\subsection{Sample Analyses}

Analyses performed on the slurry and supernatant samples collected throughout the demonstration are summarized in Table 4-4. (Note that the letter " $X$ " identifies analyses that were performed). Details of the analyses are presented following the table.

Table 4-4. Summary of Analyses

\begin{tabular}{|l|c|c|c|c|c|}
\hline \multirow{2}{*}{ Analysis } & \multicolumn{2}{|c|}{ Before Washing } & During Wash Cycles & \multicolumn{2}{c|}{ After Washing } \\
\cline { 2 - 6 } & Slurry & Supernatant & Decant Solutions & Slurry & Supernatant \\
\hline \hline Solids distribution & $\mathrm{X}$ & $\mathrm{X}$ & & $\mathrm{X}$ & $\mathrm{X}$ \\
\hline Density & $\mathrm{X}$ & $\mathrm{X}$ & $\mathrm{X}$ & $\mathrm{X}$ & $\mathrm{X}$ \\
\hline Rheology & $\mathrm{X}$ & & & $\mathrm{X}$ & \\
\hline ICP-AES & $\mathrm{X}$ & $\mathrm{X}$ & $\mathrm{X}$ & $\mathrm{X}$ & $\mathrm{X}$ \\
\hline IC & $\mathrm{X}^{*}$ & $\mathrm{X}$ & $\mathrm{X}$ & $\mathrm{X}^{*}$ & $\mathrm{X}$ \\
\hline CVAA & $\mathrm{X}$ & $\mathrm{X}$ & $\mathrm{X}$ & $\mathrm{X}$ & $\mathrm{X}$ \\
\hline Base titration & & $\mathrm{X}$ & $\mathrm{X}$ & & $\mathrm{X}$ \\
\hline TIC & & $\mathrm{X}$ & $\mathrm{X}$ & & $\mathrm{X}$ \\
\hline
\end{tabular}

*Oxalate was the only anion quantified for the slurry samples 
Solids distribution: Total solids and dissolved solids contents were determined by performing wet and dry weight measurements of slurry and supernatant aliquots, respectively, and quantifying the ratios of dry weight to wet weight. Dry weights were measured after driving water from the samples at a nominal temperature of $100-110^{\circ} \mathrm{C}$. For each type of sample, the supernatant aliquots were generated by passing the slurry through a $0.45 \mu \mathrm{m}$ filtration membrane. Four slurry aliquots and four supernatant aliquots of each sample were utilized for the measurements, along with a sodium chloride standard solution. The mass of each aliquot was $\sim 3.0 \mathrm{~g}$, and the dryings were performed in alumina crucibles. Insoluble solids content and soluble solids content were then calculated based on the total solids and dissolved solids measurements. All solids distribution measurements were performed in the Shielded Cells. The full procedure for quantifying the solids distribution is given in ITS-0078 of the L29 Manual.

Density: Densities of the unwashed and washed test slurry were quantified by dividing the total slurry mass by the volume indicated on the pre-calibrated sample vessel (a 2-L volume-calibrated bottle for the unwashed slurry and a 1-L volume-calibrated bottle for the washed slurry). In contrast, supernatant densities were determined by weighing aliquots of the decant solutions in volume-calibrated pipet tips (nominally 8-9 $\mathrm{mL}$ each). Four supernatant density measurements were performed for each sample. All density measurements were performed in the Shielded Cells. The full procedure for performing the supernatant density measurements is given in ITS-0118 of the L29 Manual. ${ }^{10}$

Rheology: Yield stresses and consistencies were determined by generating "flow curves"of shear stress as a function of shear rate. The flow curve data were acquired using a Haake RV-30 viscometer equipped with the MVI rotor, at a temperature of $25^{\circ} \mathrm{C}$. The shear rate was increased from $0-600 / \mathrm{s}$ over a five minute period, held at $600 / \mathrm{s}$ for one minute, and then reduced from $600-0 /$ s over a five minute period. The yield stress was determined by extrapolating the linear portion of the "DOWN" flow curve back to the Y-axis. The consistency was determined by calculating the slope of the linear portion of the "DOWN" curve. Two rheology measurements were performed on each sample. All rheology measurements were performed in the Shielded Cells. The full procedure for performing the rheology measurements is given in ITS-0086 of the L29 Manual. ${ }^{11}$

Slurry Digestions: Three types of slurry digestions were performed: 1) aqua regia (AR) dissolution; 2) sodium peroxide fusion (PF); and 3) mixed acid dissolution. Each digestion was performed on four separate slurry aliquots. In the case of the AR and PF digestions, the mass of each slurry aliquot was $\sim 0.85 \mathrm{~g}$ and the final volume of digest solution was $250 \mathrm{~mL}$. In the case of the mixed acid digestion, the mass of each slurry aliquot ranged from $\sim 0.85 \mathrm{~g}$ to $\sim 1.1 \mathrm{~g}$ ( $\sim 0.85 \mathrm{~g}$ for the unwashed slurry and $\sim 1.1 \mathrm{~g}$ for the final washed slurry) and the final volume of digest solution was $100 \mathrm{~mL}$. All digestions were performed in the Shielded Cells. Details of the digestion methods are given in the Analytical Development procedures/documents. ${ }^{12,13,14}$

Supernatant dilution and acidification: Two sets of solutions were prepared for the supernatant samples. In the first set, samples were diluted by a factor of $\sim 10$ utilizing de- 
ionized water. In the second set, samples were diluted by a factor of $\sim 50$ utilizing a 1-2 $\mathrm{M}$ nitric acid solution. In each case, four replicate sample aliquots were prepared for analysis. All dilution/acidification was performed in the Shielded Cells.

ICP-AES: Non-volatile metals were quantified using inductively coupled plasma-atomic emission spectroscopy (ICP-AES). These analyses were performed outside of the Shielded Cells by Analytical Development. For slurry samples, measurements of nonvolatile metals except aluminum and silicon were made utilizing the AR digest solutions. In contrast, measurements of aluminum and silicon in slurry were made using the PF digest solutions. For supernatant analyses, ICP-AES measurements were performed on sample aliquots that had been acidified and diluted.

IC: Anions were quantified using ion chromatography (IC). These analyses were performed outside of the Shielded Cells by Analytical Development. For slurry samples, oxalate was measured utilizing the mixed acid digest solutions. For supernatant samples, chloride, fluoride, nitrate, nitrite, oxalate, sulfate, and phosphate were measured using the non-acidified diluted aliquots.

CVAA: Mercury was quantified using cold vapor atomic absorption (CVAA) spectroscopy. This analysis was performed outside of the Shielded Cells by Analytical Development. For slurry samples, mercury was measured using the AR digest solutions. For supernatant samples, mercury was measured using the non-acidified diluted aliquots.

Base titration: Free hydroxide in solution was quantified using base titration. This analysis was performed outside of the Shielded Cells by Analytical Development. Only non-acidified diluted supernatant samples were analyzed by this method.

TIC: Carbonate in solution was quantified using the total inorganic carbon (TIC) method. This analysis was performed by Analytical Development outside of the Shielded Cells. Only non-acidified diluted supernatant samples were analyzed by this method.

\subsection{RESULTS AND DISCUSSION}

\subsection{Sludge Settling Prior to Washing}

Settled sludge heights as a function of time are given in Table 5-1 and Figure 5-1. Note that: a) the data in this plot refer to settling of the unwashed test slurry in the 2-L container (prior to transferring the material to the 1-L container); and b) the horizontal dotted lines shown at 9.9 and $7.1 \mathrm{~cm}$, respectively, correspond to SRR's targeted "tank fill height" (198 inches) and "after decant height" (147 inches) conditions.

As shown in the figure, the initial slurry height $(12.2 \mathrm{~cm})$ was about $20 \%$ higher than the targeted fill height (top dotted line). This indicates that the insoluble solids content of the initial unwashed test slurry was about $20 \%$ lower than the targeted concentration. This situation is reflective of the low settling rate that occurred while generating the slurry. 
Table 5-1. Sludge Settling Prior to Washing (2-L Vessel)

\begin{tabular}{|c|c|}
\hline Settling Time, days & Settled Sludge Height, cm \\
\hline 0 & 12.2 \\
\hline 4 & 10.2 \\
\hline 5 & 9.5 \\
\hline 6 & 9.1 \\
\hline 7 & 8.8 \\
\hline 8 & 8.6 \\
\hline 12 & 8.3 \\
\hline 13 & 8.3 \\
\hline 14 & 8.2 \\
\hline
\end{tabular}

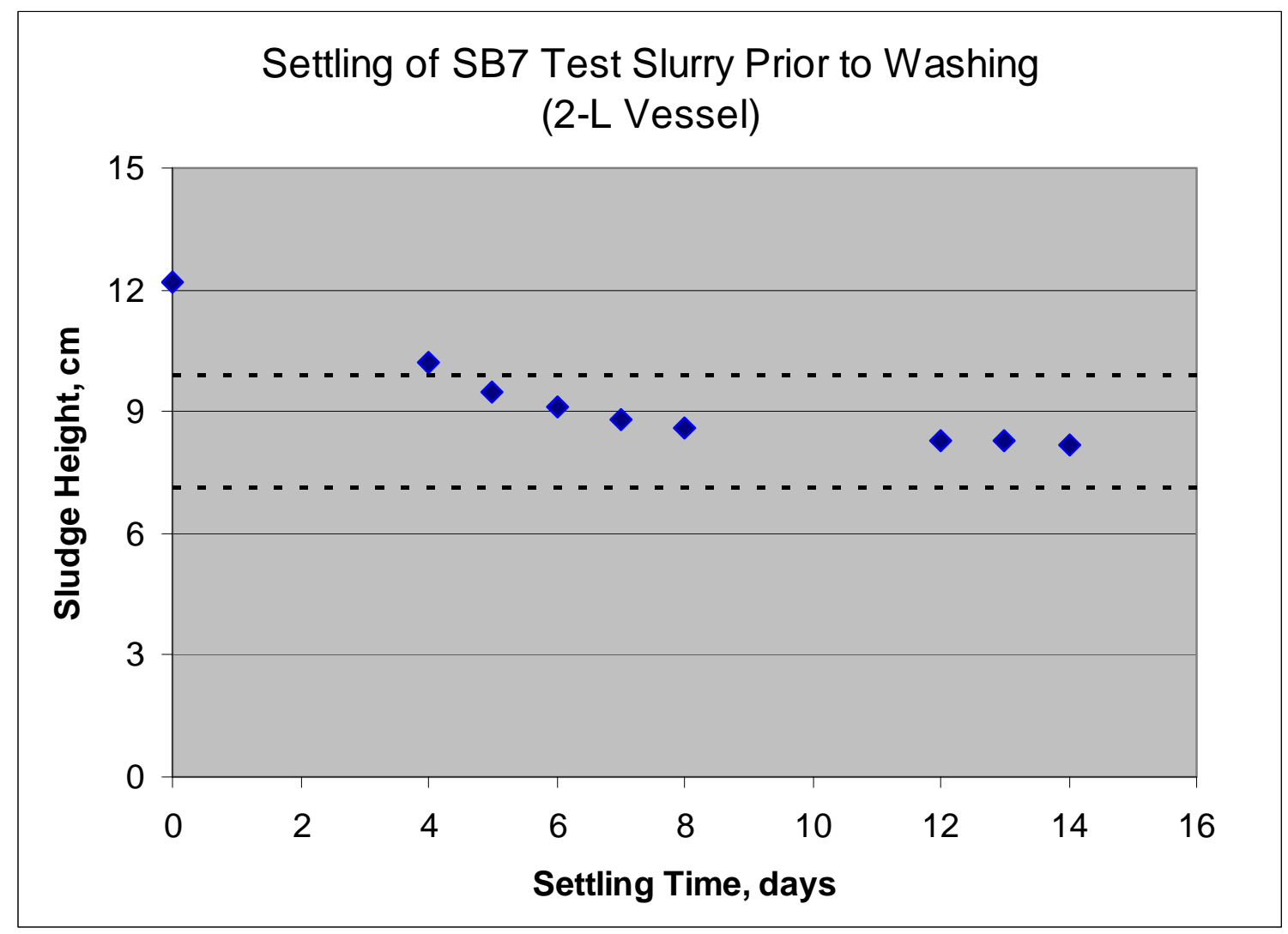

Figure 5-1. Settled Sludge Height as a Function of Time (Prior to Washing)

After 14 days settling, the sludge height $(8.2 \mathrm{~cm})$ was significantly lower than the targeted fill height, although it was higher than the targeted "after decant height" (lower dotted line) by about $15 \%$. Unfortunately, further settling of the sludge was not practical, since the settling rate had become very low by the fourteenth day.

Removal of free supernatant following the settling period brought the total slurry height to $8.7 \mathrm{~cm}$, which was about midway between the targeted "fill" and "after decant" heights. 
The net impact of this situation was that the volume of the first wash solution added (which was added to the targeted fill height) was about half the targeted size.

\subsection{Sludge Settling During Wash Cycles}

Settled sludge heights are given as functions of time and wash cycle in Table 5-2 and Figure 5-2. Note that: a) the data refer to settling of the slurry in the 1-L container (after transferring the material from the 2-L container); b) sludge settling was tracked for each of the seven wash cycles (identified as Washes A-G) and for the final sludge concentration step performed without adding more wash solution (identified as "After G'); and c) the horizontal dotted lines shown in the figure at 13.9 and $10.3 \mathrm{~cm}$ correspond to SRR's targeted "tank fill height" (198 inches) and "after decant height" (147 inches) conditions, respectively.

Table 5-2. Sludge Settling During the Wash Cycles (1-L Vessel)

\begin{tabular}{|c|c|c|c|c|c|c|c|c|}
\hline \multirow{2}{*}{$\begin{array}{l}\text { Settling } \\
\text { Time, days }\end{array}$} & \multicolumn{7}{|c|}{ Settled Sludge Height, cm } \\
\cline { 2 - 9 } & Wash A & Wash B & Wash C & Wash D & Wash E & Wash F & Wash G & After G \\
\hline \hline 0 & 14.0 & 13.9 & 13.9 & 13.9 & 13.9 & 13.9 & 13.9 & 11.2 \\
\hline 1 & & & & & 12.6 & 12.0 & 13.2 & 10.9 \\
\hline 2 & & & & & & 11.3 & 12.2 & 10.2 \\
\hline 3 & & & & & & 11.0 & 11.5 & \\
\hline 4 & 12.6 & 12.4 & & 11.9 & & & 11.2 & \\
\hline 5 & 12.3 & 12.0 & 12.2 & 11.7 & 11.1 & & & \\
\hline 6 & 11.9 & 11.8 & 12.0 & 11.4 & 11.0 & & & 9.6 \\
\hline 7 & 11.4 & 11.5 & 11.8 & 11.3 & 11.0 & 10.9 & 10.9 & 9.4 \\
\hline 8 & 11.1 & 11.4 & 11.7 & 11.2 & 10.9 & & 10.9 & 9.1 \\
\hline 9 & & & & & & & & 9.0 \\
\hline 10 & & & & & & & & \\
\hline 11 & 10.5 & 11.1 & 11.4 & 11.0 & & & & \\
\hline 12 & 10.4 & 11.0 & 11.3 & 10.9 & 10.9 & & & \\
\hline 13 & 10.3 & 10.9 & 11.2 & 10.9 & & & & 9.0 \\
\hline 14 & 10.2 & 10.9 & 11.2 & & & & & \\
\hline 16 & & & & & & & & \\
\hline
\end{tabular}




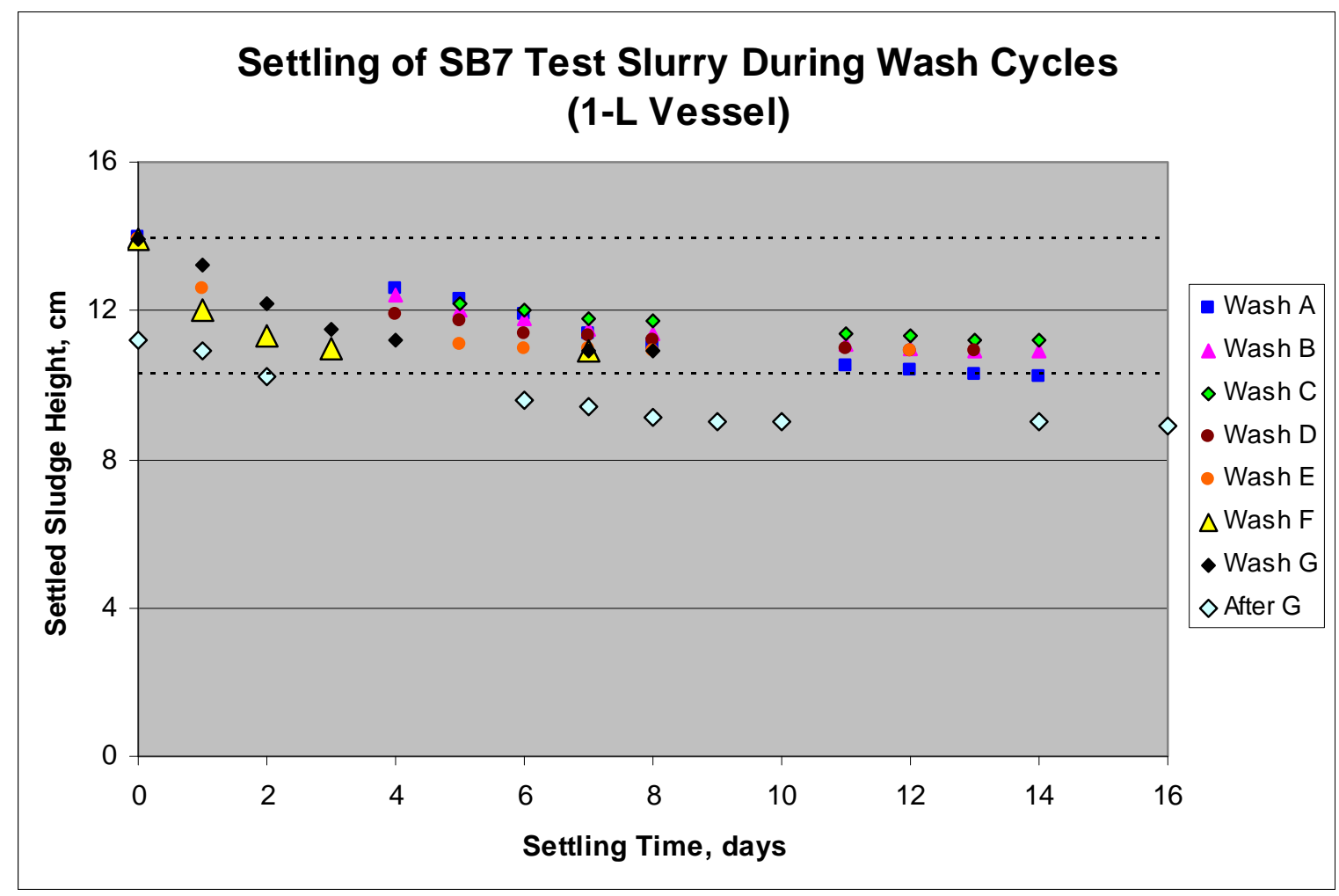

Figure 5-2. Settled Sludge Heights as Functions of Time and Wash Cycle

As shown in the figure, the sludge settling behavior varied somewhat over the various wash cycles, but on the whole, was relatively consistent with respect to sludge heights at the end of the settling periods. Settling during the first five wash cycles (Washes A-E) leveled off after a period of 12-14 days, with the final sludge heights ranging from 10.2 to $11.2 \mathrm{~cm}$. These heights were $0-10 \%$ higher than the targeted "after decant height." In contrast, settling during the sixth and seventh wash cycles (Washes F and G) leveled off after only 7-8 days, but with the same approximate final sludge height $(10.9 \mathrm{~cm})$. These results suggest that repeated washing raised the initial settling rates, but had little impact on the extent of sludge compaction.

Mixing of the decanted slurry at the end of washing (after wash G) did cause significant further settling, as evidenced by the final sludge height of $8.9 \mathrm{~cm}$ at the end of the settling period. In fact, after decanting, the final slurry height was $9.1 \mathrm{~cm}$, which was about $12 \%$ less than the targeted "after decant height." The net effect was an increase in the insoluble solids content of the slurry, due to the increased compaction.

\subsection{Characterization of Supernatants from the Various Wash Cycles}

Concentrations of constituents in the decant solutions are given in Table 5-3, and the supernatant densities of the decant solutions are given in Table 5-4. 
Table 5-3. Supernatant Constituent Concentrations as a Function of Wash Cycle

\begin{tabular}{|c|c|c|c|c|c|c|c|c|}
\hline \multirow[t]{2}{*}{ Constituent } & \multicolumn{8}{|c|}{ Supernatant Constituent Concentration, M } \\
\hline & Unwashed & Wash A & Wash B & Wash C & Wash D & Wash E & Wash F & Wash G \\
\hline Sodium (AES) & 4.7 & 3.9 & 3.4 & 2.5 & 2.1 & 1.6 & 1.1 & 0.99 \\
\hline Sulfate (IC) & 0.16 & 0.15 & 0.11 & 0.074 & 0.056 & 0.037 & 0.025 & 0.031 \\
\hline Sulfur (AES) & 0.21 & 0.18 & 0.13 & 0.099 & 0.075 & 0.046 & 0.032 & 0.030 \\
\hline Oxalate (IC) & 0.011 & 0.014 & 0.017 & 0.022 & 0.039 & 0.065 & 0.054 & 0.081 \\
\hline Nitrite (IC) & 0.81 & 0.71 & 0.89 & 0.69 & 0.57 & 0.37 & 0.28 & 0.30 \\
\hline Nitrate (IC) & 0.84 & 0.74 & 0.55 & 0.42 & 0.33 & 0.23 & 0.16 & 0.16 \\
\hline Free hydroxide (titration) & 0.75 & 0.77 & 0.47 & 0.32 & 0.30 & 0.29 & 0.12 & 0.18 \\
\hline Chloride (IC) & 0.046 & 0.040 & 0.029 & 0.023 & 0.018 & 0.012 & 0.0089 & 0.0085 \\
\hline Fluoride (IC) & $<0.007$ & $<0.007$ & $<0.007$ & $<0.007$ & $<0.007$ & $<0.007$ & $<0.007$ & $<0.007$ \\
\hline Carbonate (TIC) & 0.44 & 0.38 & 0.28 & 0.21 & 0.16 & 0.11 & 0.082 & 0.084 \\
\hline Aluminum (AES) & 0.19 & 0.16 & 0.12 & 0.093 & 0.074 & 0.048 & 0.034 & 0.030 \\
\hline Phosphate (IC) & 0.0020 & $<0.007$ & $<0.007$ & $<0.007$ & $<0.007$ & $<0.007$ & $<0.007$ & $<0.007$ \\
\hline Phosphorus (AES) & 0.0039 & 0.0034 & 0.0023 & 0.0017 & 0.0014 & 0.00087 & 0.00066 & 0.00057 \\
\hline Potassium (AES) & 0.013 & 0.013 & 0.0097 & 0.0071 & 0.0044 & 0.0033 & 0.0026 & 0.0021 \\
\hline Chromium (AES) & 0.0048 & 0.0041 & 0.0030 & 0.0023 & 0.0019 & 0.0012 & 0.00087 & 0.00079 \\
\hline Iron (AES) & 0.00010 & 0.000087 & 0.000070 & 0.00012 & 0.00010 & 0.000088 & 0.000055 & 0.00013 \\
\hline Mercury (CVAA) & 0.00025 & 0.00046 & 0.00048 & 0.00035 & 0.00026 & 0.00029 & 0.00023 & 0.00039 \\
\hline Molybdenum (AES) & 0.00045 & 0.00040 & 0.00030 & 0.00022 & 0.00019 & 0.00012 & 0.000081 & 0.000073 \\
\hline
\end{tabular}

Table 5-4. Densities of Decant Solutions

\begin{tabular}{|c|c|}
\hline $\begin{array}{c}\text { Wash Cycle } \\
\text { Descriptor }\end{array}$ & $\begin{array}{c}\text { Supernatant } \\
\text { Density, g/mL }\end{array}$ \\
\hline \hline Unwashed & 1.21 \\
\hline Wash A & 1.18 \\
\hline Wash B & 1.17 \\
\hline Wash C & 1.12 \\
\hline Wash D & 1.10 \\
\hline Wash E & 1.08 \\
\hline Wash F & 1.05 \\
\hline Wash G & 1.07 \\
\hline
\end{tabular}


Three general categories of constituents are included in Table 5-3: 1) constituents that provide a basis for assessing washing effectiveness (sodium, sulfur, and oxalate);

2) constituents related to tank corrosion chemistry (anions such as nitrate, nitrite, and free hydroxide); and 3) constituents measured at concentrations above the minimum detection limits (chromium, iron, mercury, molybdenum).

Four clearly different concentration trends can be found in the data presented in Table 5-3. The most abundant trend applies to the soluble constituents, for which concentrations typically dropped from one wash cycle to the next, and the overall concentration reduction over the series of washes was $80-85 \%$. Included among these constituents are sodium, sulfur, nitrate, and chloride. The largest removal of these constituents occurred in the early wash cycles, since the vast majority of each of these constituents was in the liquid phase when washing began. Note that the supernatant phase concentration of sodium was approximately one molar (which was the targeted sodium endpoint) when the seventh wash cycle (Wash G) was completed.

The second trend applies to nitrite, which is soluble but augmented by the sodium nitrite of the inhibited water washing solutions (particularly the second washing solution that contained extra sodium nitrite). In the case of nitrite, the concentration decreases in all wash cycles except the second (Wash B) and the overall concentration reduction over the series of washes is $60-65 \%$.

The third trend applies to oxalate, which is relatively insoluble at the start of washing, but becomes relatively soluble at the end of washing, as the sodium molarity drops to one or less. In the case of oxalate, the concentration in the final wash solution $(0.081 \mathrm{M})$ is an order of magnitude higher than the concentration prior to washing $(0.011 \mathrm{M})$. As such, the largest removal of oxalate occurred during the final wash cycle (when the liquid phase oxalate concentration was the greatest).

The fourth trend applies to iron and mercury, which were relatively insoluble throughout the course of washing. As such, the fractions of each that dissolved into solution were very small and the resulting concentrations were relatively constant. To illustrate, the initial and final iron concentrations were both $\sim 1 \mathrm{E}-4 \mathrm{M}$, and the initial and final mercury concentrations were approximately the same, $\sim 3 \mathrm{E}-4$ and $\sim 4 \mathrm{E}-4 \mathrm{M}$, respectively. Removal of the relatively insoluble constituents was minor, since the vast majorities of these constituents were retained in the solid phase.

A plot containing examples of the four concentration trends is given in Figure 5-3. Specifically, this plot shows the concentration profiles for sodium, nitrite, sulfur, oxalate, and iron.

Removal of soluble constituents is reflected in the supernatant densities, which dropped from 1.21 to $1.07 \mathrm{~g} / \mathrm{mL}$ over the course of the washing, as shown in Table 5-4. Note that the supernatant density at the end of Wash $\mathrm{G}(1.07 \mathrm{~g} / \mathrm{mL})$ was slightly higher than the supernatant density at the end of Wash F. It is thought that this increase was due to a combination of measurement uncertainty and the increased sodium oxalate concentration. 


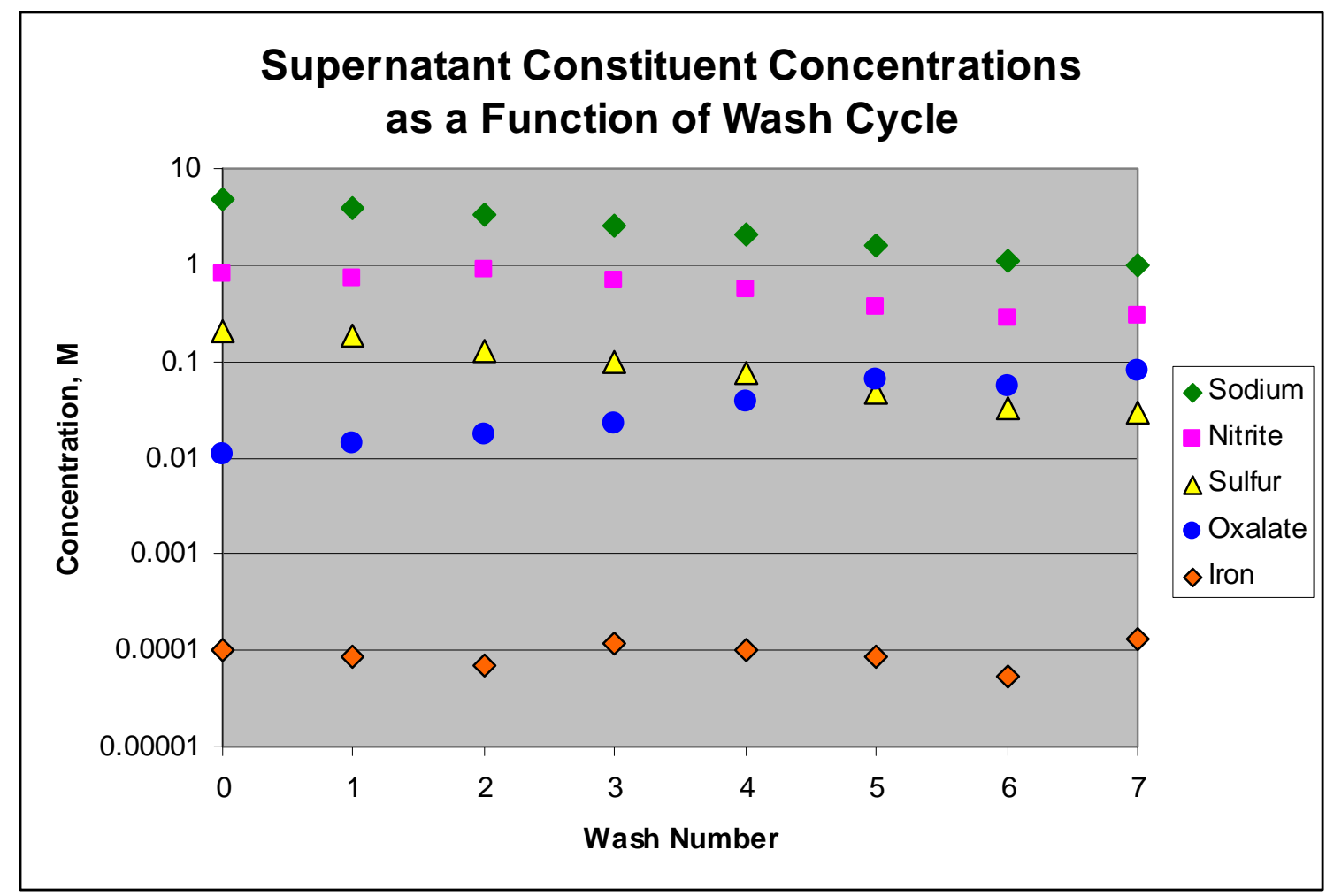

Figure 5-3. Supernatant Constituent Concentrations Plotted Versus Wash Cycle

\subsection{Physical Properties of Unwashed and Washed Sludge}

Physical properties of the unwashed and washed sludge are given in Table 5-5.

Consistent with expectations, the slurry and supernatant densities of the washed sludge were lower than those of the unwashed sludge, due to the large removal of soluble solids. Specifically, washing reduced the soluble solids content from $\sim 22 \mathrm{wt} \%$ to $\sim 6 \mathrm{wt} \%$. In contrast, the insoluble solids content increased from $\sim 8 \mathrm{wt} \%$ to $\sim 18 \mathrm{wt} \%$, as settling and removal of liquid effectively concentrated the sludge. Not unexpectedly, the yield stress and consistency of the washed sludge were significantly higher than those for the unwashed sludge, due in large part to the effects of the higher sludge concentration. Per visual observations, the unwashed slurry poured like broth - the washed slurry like catsup.

Table 5-5. Physical Properties of Unwashed and Washed Sludge

\begin{tabular}{|l|c|c|}
\hline Physical Property & Unwashed & Washed \\
\hline \hline Slurry density, g/mL & 1.26 & 1.22 \\
\hline Supernatant density, g/mL & 1.21 & 1.06 \\
\hline Total solids, wt\% of slurry & 29.9 & 24.2 \\
\hline Insoluble solids, wt\% of slurry & 8.1 & 18.0 \\
\hline Soluble solids, wt\% of slurry & 21.8 & 6.2 \\
\hline Dissolved Solids, wt\% of supernatant & 23.7 & 7.6 \\
\hline Yield Stress, Pa & 4.1 & 35 \\
\hline Consistency, cP & 12 & 25 \\
\hline
\end{tabular}


The yield stress of the washed sludge was sufficiently high $(35 \mathrm{~Pa})$ that potential difficulties associated with pumping of the material would be anticipated. Consistent with such problems, the DWPF design basis specifies a maximum yield stress of $15 \mathrm{~Pa}^{15}$

Insight into the rheological impacts of washing and insoluble solids content can be gained from yield stress and consistency data for the respective sludges (unwashed and washed) over a range of insoluble solids contents. Such data are given in Table 5-6 and plotted in Figures 5-4 and 5-5, respectively. Note that the data: a) for the unwashed sludge at 8.1 wt $\%$ IS and the washed sludge at $18.0 \mathrm{wt} \%$ IS are the same data presented in Table 5-5; b) for the unwashed sludge at $11.4 \mathrm{wt} \%$ IS apply to the initial slurry after the decant was performed; and c) for the washed sludge at 12.3 and $15.0 \mathrm{wt} \%$ IS apply to dilutions of the final slurry performed by adding back portions of the final decant solution.

Table 5-6. Rheological Properties as a Function of Insoluble Solids Content

\begin{tabular}{|l|c|c|c|}
\hline $\begin{array}{l}\text { Slurry } \\
\text { Type }\end{array}$ & $\begin{array}{c}\mathrm{Wt} \% \\
\mathrm{IS}\end{array}$ & $\begin{array}{c}\text { Yield Stress, } \\
\text { Pa }\end{array}$ & $\begin{array}{c}\text { Consistency, } \\
\mathrm{cP}\end{array}$ \\
\hline \hline \multirow{2}{*}{ Unwashed } & 8.1 & 4.1 & 12 \\
\cline { 2 - 4 } & 11.4 & 10 & 17 \\
\hline \multirow{3}{*}{ Washed } & 12.3 & 10 & 11 \\
\cline { 2 - 4 } & 15.0 & 17 & 15 \\
\cline { 2 - 4 } & 18.0 & 35 & 25 \\
\hline
\end{tabular}

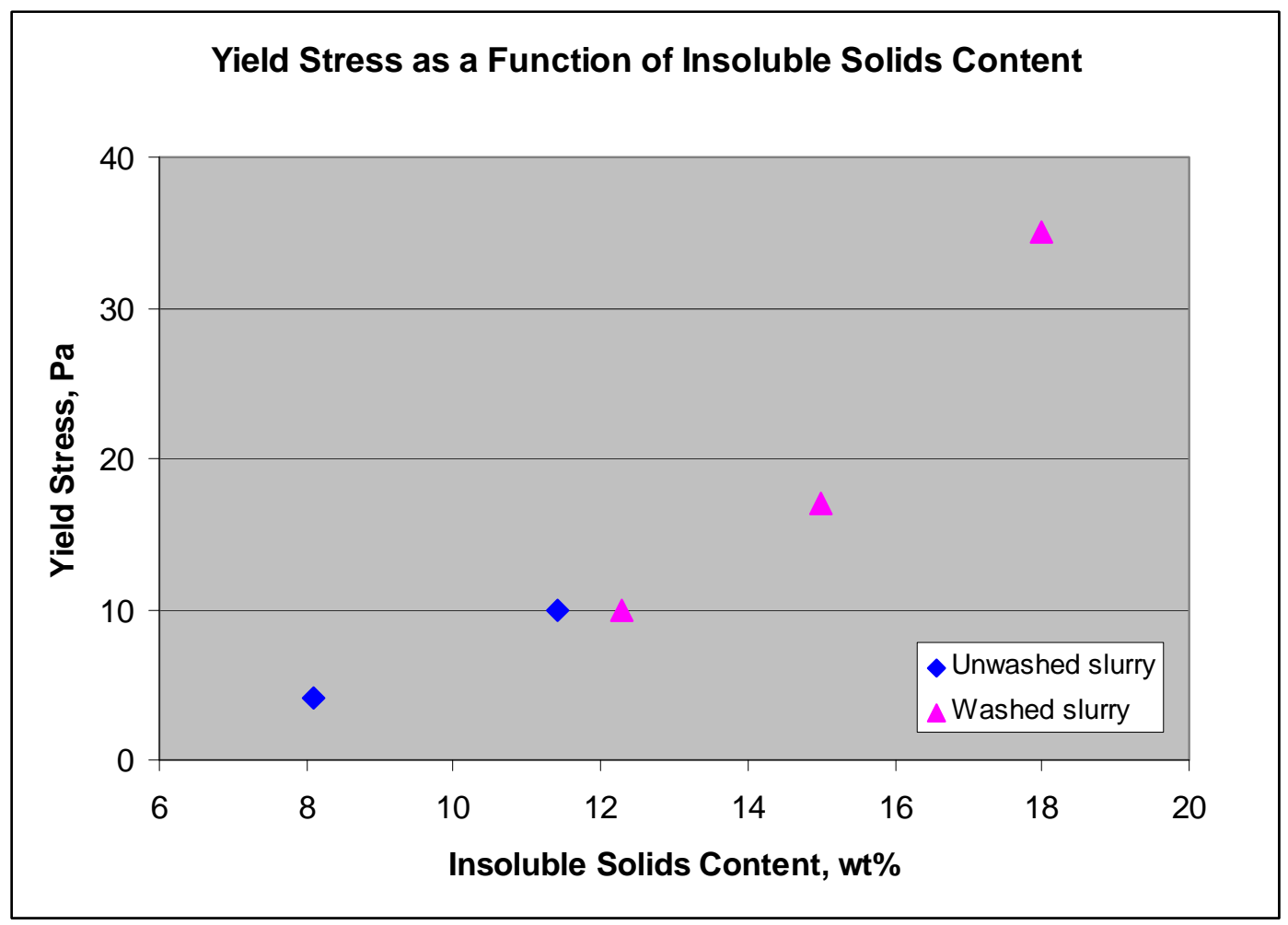

Figure 5-4. Yield Stress as a Function of Insoluble Solids Content 


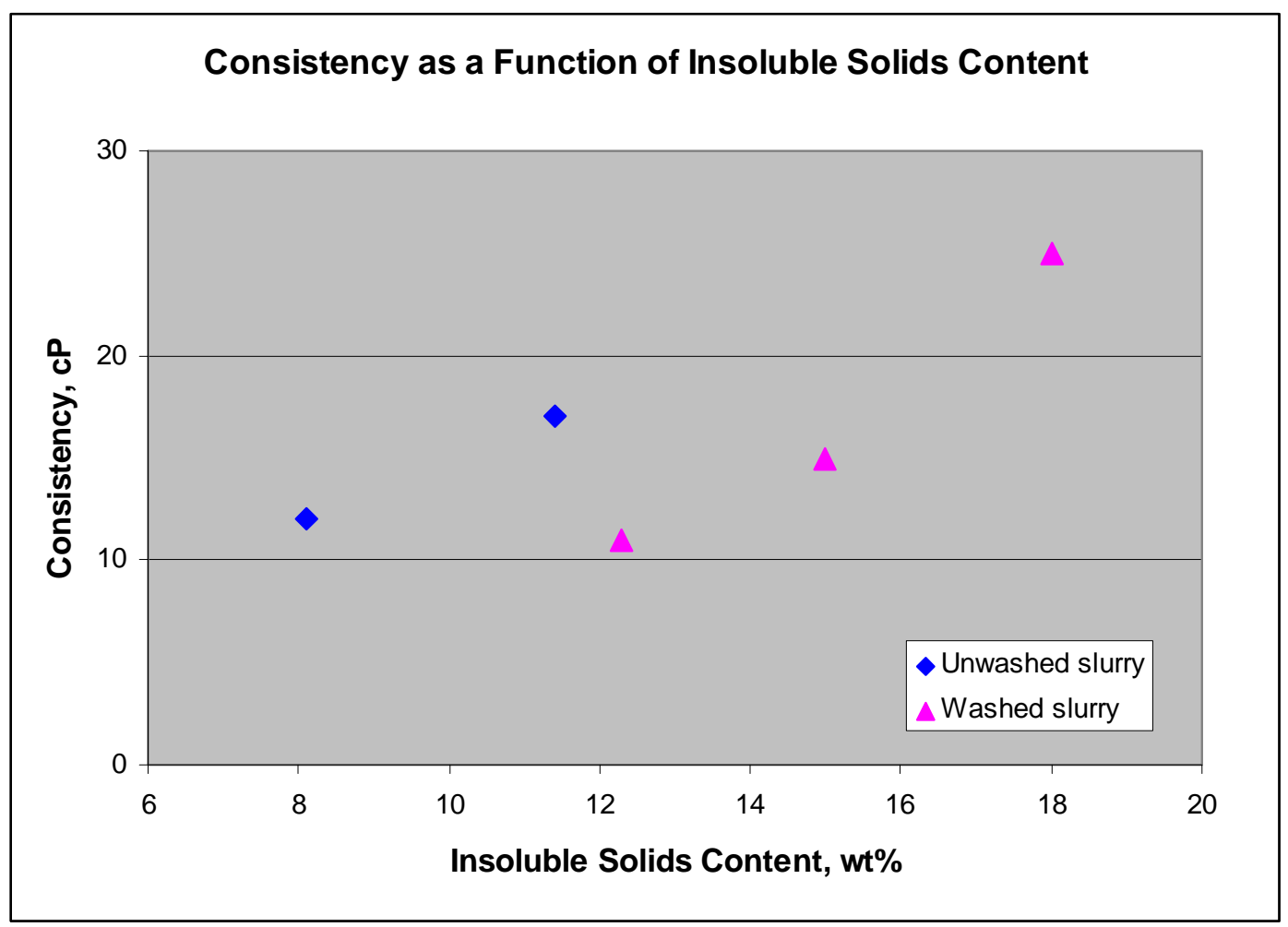

Figure 5-5. Consistency as a Function of Insoluble Solids Content

As shown in Figure 5-4, the yield stress increased with the insoluble solids content in a near-continuum that seems to apply to both the unwashed and washed slurry. This suggests that the yield stress was impacted primarily by insoluble solids, not by soluble solids. Based on these data, a maximum insoluble solids content of $\sim 14 \mathrm{wt} \%$ would be necessary to meet the DWPF design basis limit of $15 \mathrm{~Pa}$.

In contrast, as shown in Figure 5-5, the consistency seemed to increase with both insoluble solids and soluble solids. The impacts of soluble solids can be seen by comparing the relative position of the "unwashed slurry curve" with that of the "washed slurry curve." Clearly, for a given insoluble solids content, a higher consistency would be expected for the unwashed slurry than for the washed slurry. This is particularly evident in the data points around $11-12 \mathrm{wt} \%$ insoluble solids, where the consistency of the unwashed slurry is around $50 \%$ higher that that of the washed slurry.

\subsection{Chemical Composition of Unwashed and Washed Sludge}

Concentrations of elemental constituents in the unwashed and washed sludge are given in Table 5-7, and concentrations of oxalate in the unwashed and washed sludge are given in Table 5-8. Note that the elemental constituent concentrations are given on a total solids basis (wt $\%$ of total solids), while the oxalate concentrations are given on a slurry basis (milligrams per kilogram of slurry). 
Table 5-7. Elemental Constituent Concentrations in Unwashed and Washed Sludge

\begin{tabular}{|c|c|c|}
\hline \multirow[t]{2}{*}{ Constituent } & \multicolumn{2}{|c|}{$\mathrm{Wt} \%$ of $\mathrm{TS}$} \\
\hline & Unwashed & Washed \\
\hline $\mathrm{Al}$ & 7.2 & 14 \\
\hline $\mathrm{Ba}$ & 0.033 & 0.080 \\
\hline $\mathrm{Ca}$ & 0.21 & 0.50 \\
\hline $\mathrm{Cd}$ & 0.0095 & 0.024 \\
\hline $\mathrm{Ce}$ & 0.052 & 0.11 \\
\hline $\mathrm{Co}$ & 0.0039 & 0.011 \\
\hline $\mathrm{Cr}$ & 0.078 & 0.047 \\
\hline $\mathrm{Cu}$ & 0.021 & 0.053 \\
\hline $\mathrm{Fe}$ & 4.6 & 11 \\
\hline $\mathrm{Hg}$ & 0.47 & 0.96 \\
\hline $\mathrm{K}$ & 0.13 & 0.045 \\
\hline $\mathrm{La}$ & 0.025 & 0.063 \\
\hline $\mathrm{Mg}$ & 0.10 & 0.23 \\
\hline $\mathrm{Mn}$ & 0.96 & 2.4 \\
\hline Mo & 0.014 & $<0.10$ \\
\hline $\mathrm{Na}$ & 30 & 12 \\
\hline $\mathrm{Ni}$ & 0.80 & 2.1 \\
\hline $\mathrm{P}$ & 0.074 & 0.046 \\
\hline $\mathrm{S}$ & 1.5 & 0.45 \\
\hline $\mathrm{Si}$ & 0.46 & 1.1 \\
\hline $\mathrm{Sr}$ & 0.015 & 0.037 \\
\hline $\mathrm{Th}$ & 0.24 & 0.60 \\
\hline $\mathrm{Ti}$ & 0.0072 & 0.017 \\
\hline $\mathrm{U}$ & 1.3 & 3.8 \\
\hline $\mathrm{Zn}$ & 0.017 & 0.040 \\
\hline $\mathrm{Zr}$ & 0.073 & 0.092 \\
\hline
\end{tabular}

Table 5-8. Oxalate Concentrations of Unwashed and Washed Slurries

\begin{tabular}{|l|c|c|}
\hline \multirow{2}{*}{ Constituent } & \multicolumn{2}{|c|}{$\mathrm{mg} / \mathrm{kg}$ slurry } \\
\cline { 2 - 3 } & Unwashed & Washed \\
\hline Oxalate & 8700 & 9900 \\
\hline
\end{tabular}

Two clearly different concentration trends can be found in the data presented in Table 5-7. The most abundant trend applies to the insoluble elements, for which concentrations in the total solids of the washed sludge were on the order of 2-3 times those of the unwashed sludge. Included among these elements are many metals including aluminum, calcium, iron, mercury, manganese, nickel, thorium, and uranium, to name a few. (Note that the increased concentrations in the total solids of the washed sludge were indicative of the extent that the sludge was concentrated). 
The second trend applies to the highly soluble elements, for which concentrations in the total solids of the washed sludge were appreciably lower than those in the unwashed sludge (40-70\% lower depending on the relative solubility). Included among these elements are chromium, potassium, sodium, phosphorus, and sulfur. Note that: a) the sodium concentrations in the total solids of the unwashed and washed sludges were 30 and $12 \mathrm{wt} \%$, respectively; and $\mathrm{b}$ ) the sulfur concentrations in the total solids of the unwashed and washed sludges were 1.5 and $0.45 \mathrm{wt} \%$, respectively.

As shown in Table 5-8, the concentrations of oxalate in the unwashed and washed sludges were 8700 and $9900 \mathrm{mg}$ per kg slurry, respectively. The implications of these concentrations with respect to removal of oxalate are addressed below, along with removal of sodium and sulfur.

\subsection{Reduction in Sodium, Sulfur, and Oxalate}

Masses of sodium, sulfur, and oxalate in the unwashed and washed sludge are given in Table 5-9. Also given in the table are the unwashed and washed test slurry masses, and the percentages of sodium, sulfur, and oxalate that were removed during washing.

Table 5-9. Removal of Oxalate, Sulfur, and Sodium

\begin{tabular}{|l|c|c|c|}
\hline Parameter & Unwashed & Washed & Delta \\
\hline \hline Test slurry mass, g & 1303 & 650 & $-50 \%$ \\
\hline Sodium mass in slurry, g & 117 & 19 & $-85 \%$ \\
\hline Sulfur mass in slurry, g & 5.8 & 0.71 & $-90 \%$ \\
\hline Oxalate mass in slurry, g & 11.3 & 6.4 & $-45 \%$ \\
\hline
\end{tabular}

As shown in the table, the final test slurry mass was approximately half the initial test slurry mass. This is reflective of the significant increase in insoluble solids concentration (Table 5-5) due to the effective removal of soluble solids and supernatant. The net effect was that large fractions of the highly soluble constituents were removed. For the cases of sodium and sulfur, respectively, the constituent masses in the washed sludge were calculated to be 85 and $90 \%$ lower than the masses in the unwashed sludge. The difference between these two values is attributed to the effect of the sodium introduced in the wash solutions (particularly in the second wash solution) and/or the analytical uncertainty.

In contrast, the mass of oxalate in the washed sludge was calculated to be $45 \%$ lower than the mass in the unwashed sludge. The moderate reduction in oxalate (as compared to sodium and sulfur) is consistent with the expectation that the solubility of oxalate was low at the start of washing and did not become significant until the later wash cycles (when the concentration of sodium approached one molar). 


\subsection{Balancing Physical and Chemical Requirements}

As previously identified, the washing scheme of this demonstration reduced the supernatant sodium concentration to the desired endpoint $(\sim 1 \mathrm{M})$, reduced the sulfur content by an order of magnitude, and reduced the oxalate content by a factor of approximately two. It also increased the insoluble solids content of the sludge from $\sim 8$ $\mathrm{wt} \%$ to $\sim 18 \mathrm{wt} \%$, which raised the yield stress of the sludge from a manageable level of $\sim 4 \mathrm{~Pa}$ to a likely unwieldy level of $35 \mathrm{~Pa}$.

Given the $15 \mathrm{~Pa}$ yield stress max of the DWPF design basis and the potential problems associated with pumping a $35 \mathrm{~Pa}$ sludge, alternative options for reducing the final yield stress of the sludge must be considered. Clearly, the key to reducing the yield stress is to reduce the insoluble solids concentration. However, there are many approaches available for doing this and each approach impacts the final composition differently. With this in mind, an approach should be chosen based on two primary criteria: 1) practicality and 2) facilitating processing at DWPF. Descriptions of a number of possible options for reducing insoluble solids content are given below.

A. Reduce the Final Decant Volume: This approach is simple, requires less settling time, and maintains the supernatant sodium concentration. However, it reduces oxalate removal, due to the relatively large concentration of oxalate in the final decant..

B. Dilute the Final Sludge with Inhibited Water: This approach is relatively simple, requires modest additional time, and has no impact on oxalate removal. However, it reduces the supernatant sodium concentration.

C. Dilute the Final Sludge with a 1 M Sodium Solution: This approach is somewhat more complex (due to the need to supply a $1 \mathrm{M}$ sodium solution) and requires modest additional time, assuming a source of the added chemicals is available. However, it has no impact on oxalate removal and maintains the supernatant sodium concentration.

D. Perform Another Wash Cycle, and then Reduce the Final Decant Volume: This approach is simple, but requires significant additional time, due to the added wash cycle. An advantage of this approach is that it significantly increases oxalate removal. A potential disadvantage is that it reduces the supernatant sodium concentration.

E. Other Options: Additional strategies involving combinations of the options above may be worth considering depending on the compositional requirements of DWPF and on the schedule constraints. For instance, options involving additional washing coupled with supernatant sodium adjustment may be appropriate if greater oxalate removal is deemed necessary.

Selection of the most appropriate option will depend on the applicable resource constraints and the flexibility of DWPF's compositional requirements. 


\subsection{CONCLUSIONS}

1) The SB7 test slurry sludge settled slowly and with limited compactness. The net result was that seven small washes were required to bring the supernatant sodium concentration to the desired endpoint. The total duration of the wash cycles plus an additional final settling step was approximately four months.

2) The yield stress of the final washed sludge was an order of magnitude higher than the unwashed sludge. This was related to the significant increase in insoluble solids content that occurred (from $\sim 8 \mathrm{wt} \%$ to $\sim 18 \mathrm{wt} \%$ ) as the soluble solids and water were removed. The yield stress of the washed sludge was considered too high from a DWPF design basis and a pumping perspective. Dilution of the final sludge to approximately $14 \mathrm{wt} \%$ insoluble solids was necessary to reduce the yield stress to a manageable level.

3) Washing reduced the sulfur content of the sludge by an order of magnitude, and the oxalate content by a factor of approximately two. The supernatant compositions during washing indicated that the vast majority of sulfur was soluble from the start. Most of the sulfur was therefore removed during the early wash cycles. In contrast, most of the oxalate was insoluble at the start of washing and did not start becoming soluble until the later washes. As a consequence, most of the oxalate was removed during the later wash cycles, and significantly more oxalate would have been removed if washing would have continued.

4) The strategy for completing the final washing cycle must be chosen carefully to maintain the proper balance of physical and chemical requirements, particularly those relating to yield stress, sodium content, and oxalate content. 


\subsection{REFERENCES}

1 Bannochie, C. J., D. R. Click, and J. M. Pareizs. Sludge Batch 7 Preparation: Tank 4 and 12 Characterization, Savannah River National Laboratory, Aiken, SC, SRNL-STI-2010-00223, May 2010.

2 Lambert, D. P., J. M. Pareizs, and D. R. Click. Tank 7 Characterization and Washing Studies, Savannah River National Laboratory, Aiken, SC, SRNL-STI2009-00774, Rev. 1, May 2010.

3 Reboul, S. H., M. S. Hay, K. E. Zeigler, and M. E. Stone. Tank 12 Sludge Characterization and Aluminum Dissolution Demonstration, Savannah River National Laboratory, Aiken, SC, SRNL-STI-2009-00180, March 2009.

4 Colleran, H. Q. Technical Task Request: Sludge Batch 7 Washing Demonstration to Determine Sulfate/Oxalate Removal Efficiency and Settling Behavior, Savannah River Remediation, Aiken, SC, HLE-TTR-2010-011, March 23. 2010.

5 Reboul, S. H. and D. P. Lambert. Task Technical and Quality Assurance Plan for the Sludge Batch 7 Washing Demonstration to Determine Sulfate/Oxalate Removal Efficiency and Settling Behavior, Savannah River National Laboratory, Aiken, SC, SRNL-RP-2010-0068, April 21, 2010.

6 Reboul, S. H. Laboratory Notebook: Sludge Batch 7 Washing Demonstration, Savannah River National Laboratory, Aiken, SC, SRNL-NB-2010-00052, Date Opened: April 7, 2010.

7 Reboul, S. H. Laboratory Notebook: Sludge Batch 7 Washing Demonstration Part Two, Savannah River National Laboratory, Aiken, SC, SRNL-NB-201000125, Date Opened: September 7, 2010.

8 Gillam, J. H. SB6-7 041910 Planning Spreadsheet (Excel), Savannah River Remediation, Aiken, SC, April 19, 2010.

9 Pareizs, J. M. Weight Percent Solids Distribution Using a Furnace or Oven, Savannah River National Laboratory, Aiken, SC, SRNL L29 Manual, ITS-0078, March 30, 2007.

10 Bannochie, C. J. Shielded Cells Operation Supernate and Slurry Density Determination Procedure, Savannah River National Laboratory, Aiken, SC, SRNL L29 Manual, ITS-0118, March 30, 2007.

11 Hansen, E. K. Setup and Operation of the Shielded Cells Viscometer, Savannah River National Laboratory, Aiken, SC, SRNL L29 Manual, ITS-0086, August 31, 2007. 
12 Analytical Development. Aqua Regia Dissolution of Sludge for Elemental Analysis, Savannah River National Laboratory, Aiken, SC, SRNL L16.1 Manual, ADS-2226, October 2009.

13 Analytical Development. Alkali Fusion Dissolution of Sludge and Glass for Elemental and Anion Analysis, Savannah River National Laboratory, Aiken, SC, SRNL L16.1 Manual, ADS-2502, March 2008.

14 Coleman, C. J. Method to Determine Oxalate in High-Level Sludge by Ion Chromatography, WSRC-TR-2002-00497, Savannah River Site, Aiken, SC, October 28, 2002.

15 Basic Data Report: Defense Waste Processing Facility Sludge Plant, Savannah River Plant 200-S Area, Savannah River Site, Aiken, SC, DPSP-80-1033, Revision 10, July 1992. 


\section{APPENDIX A: FLOW CURVES FROM RHEOLOGY MEASUREMENTS}
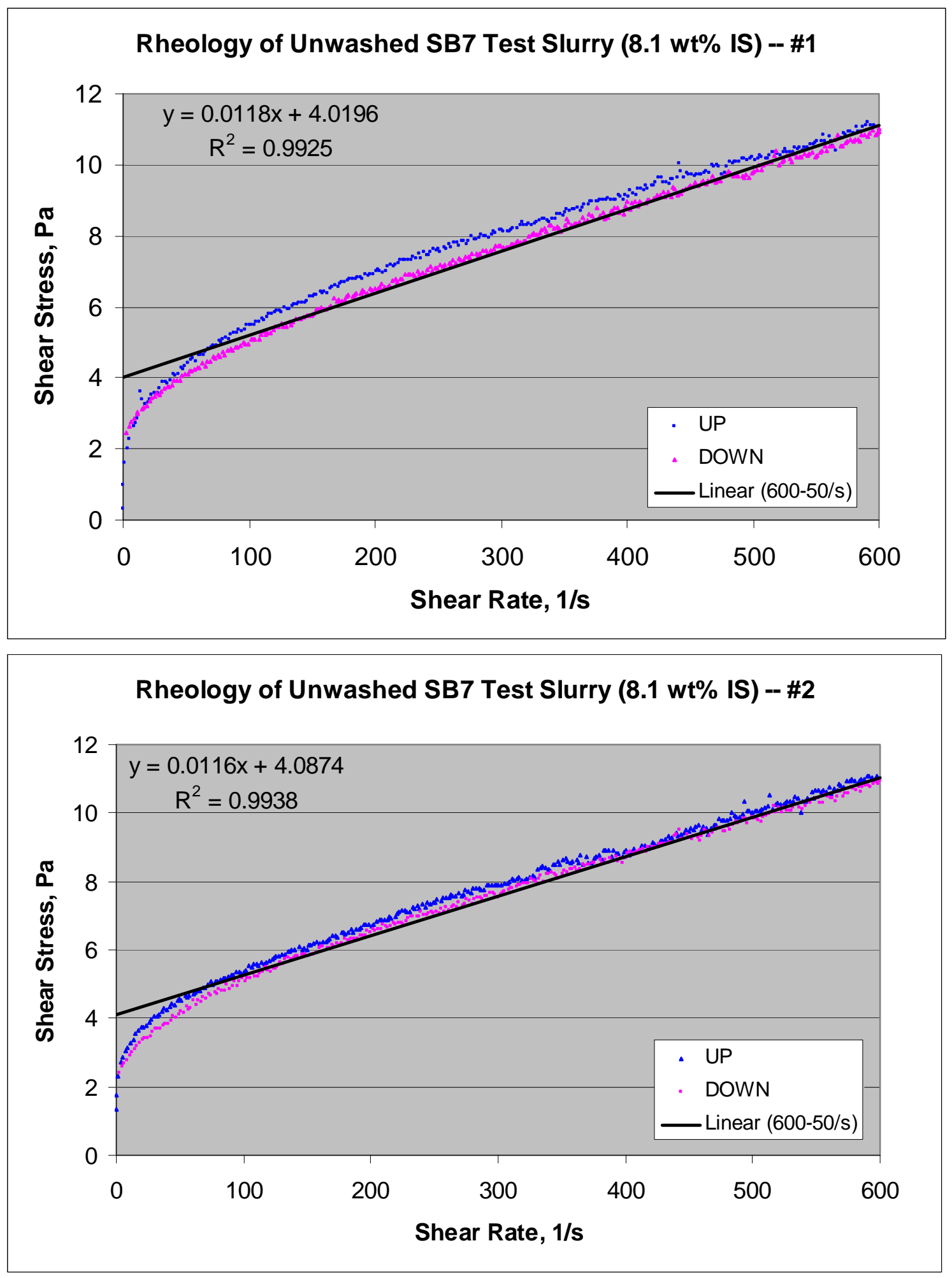

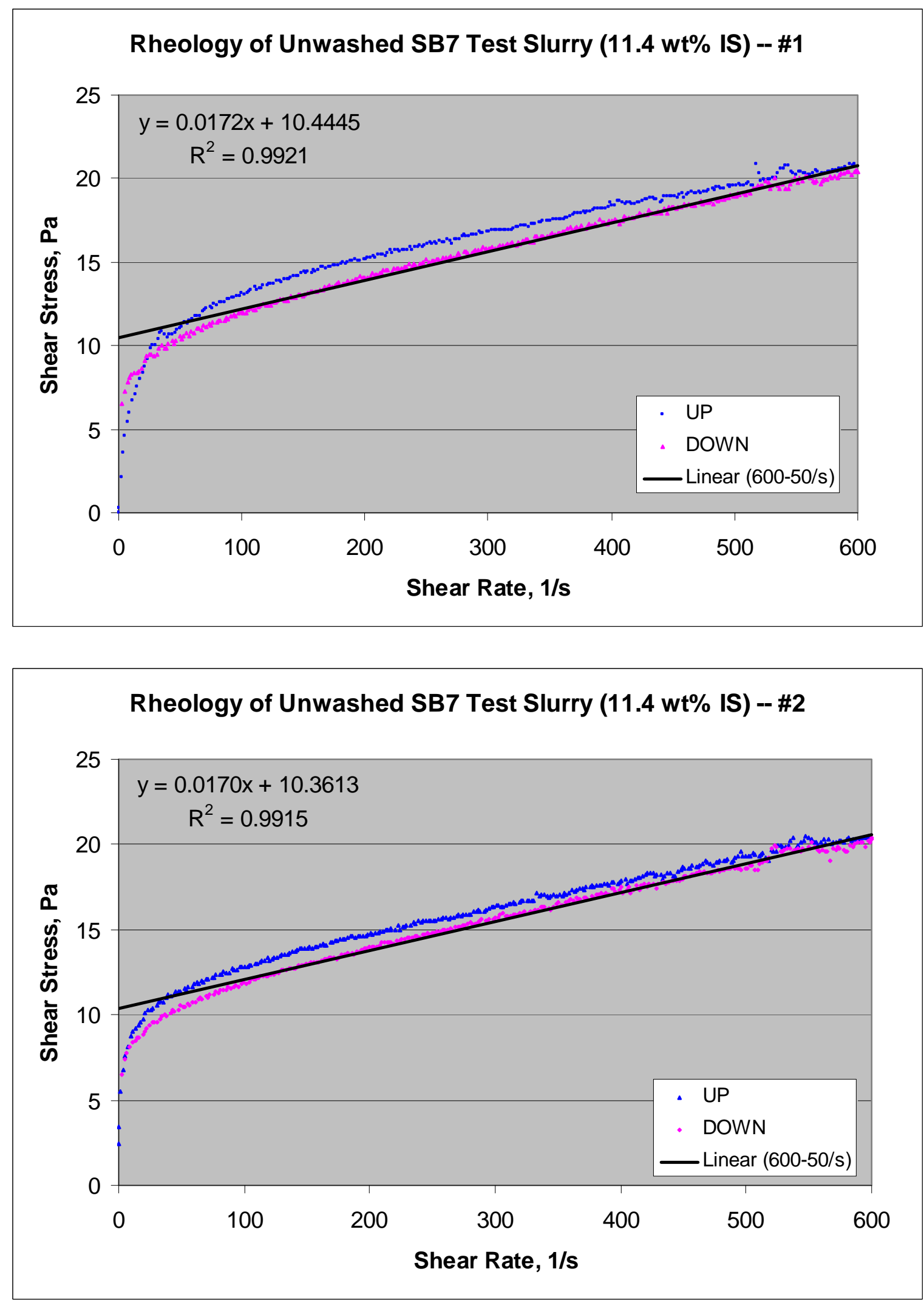

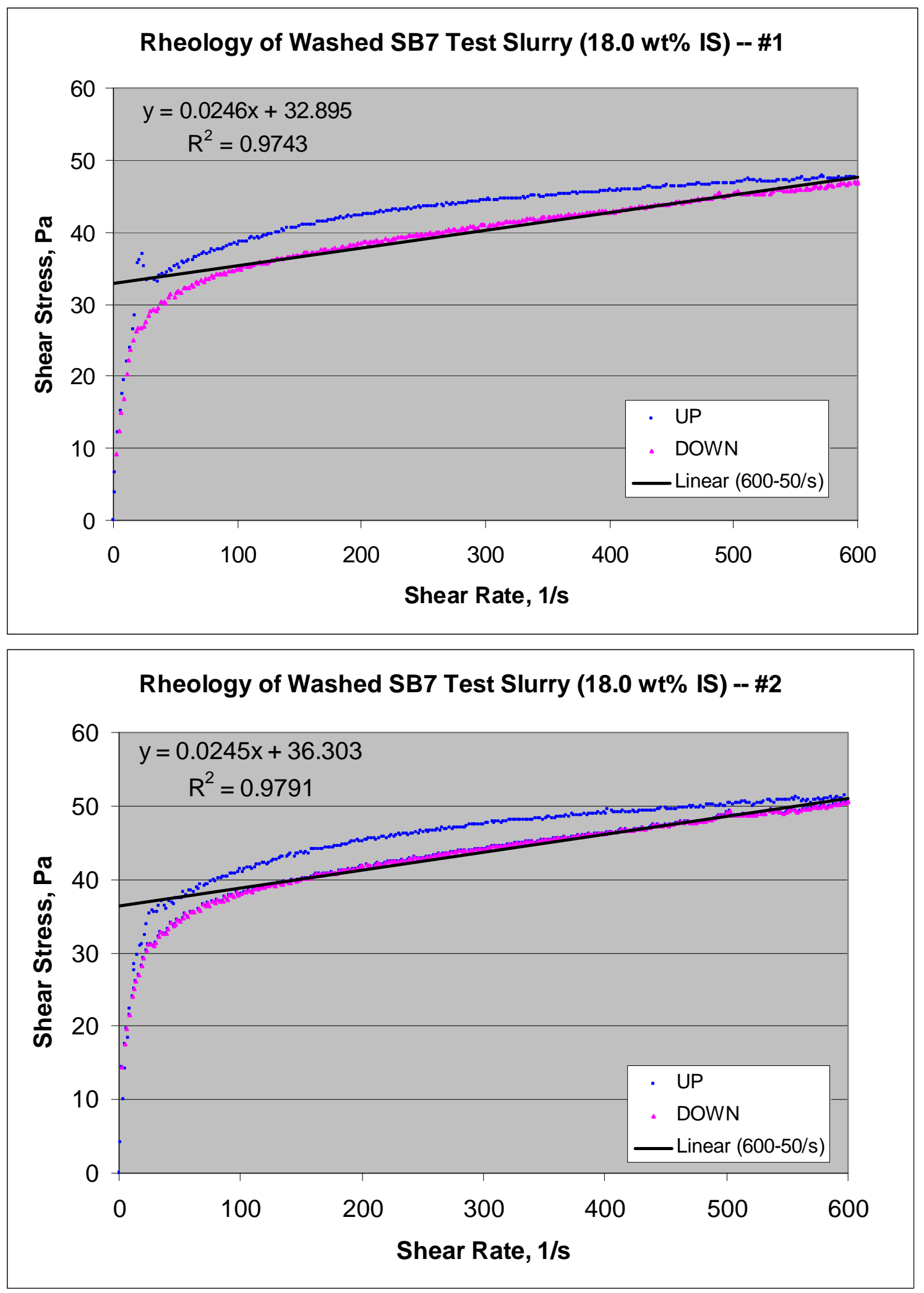

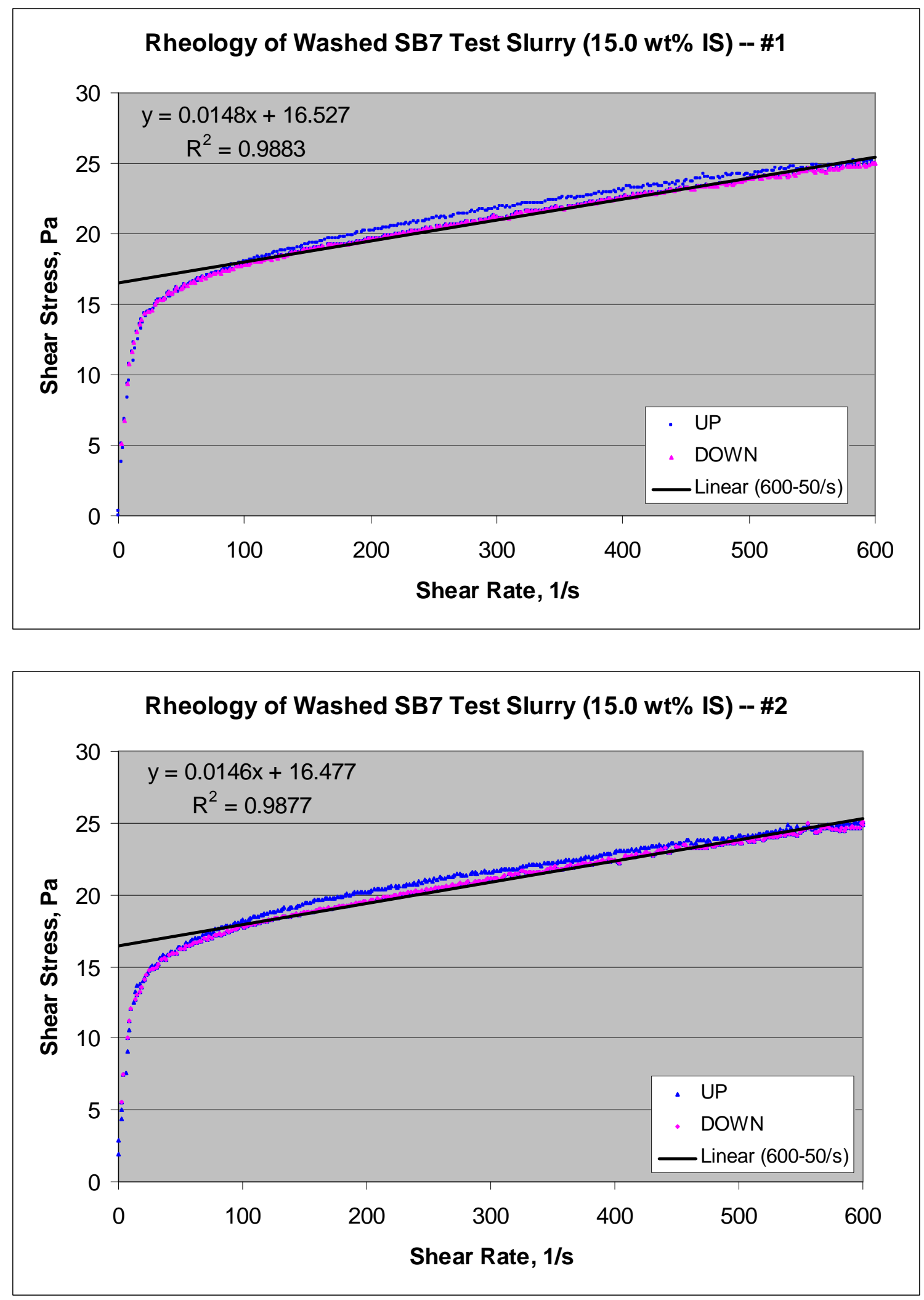

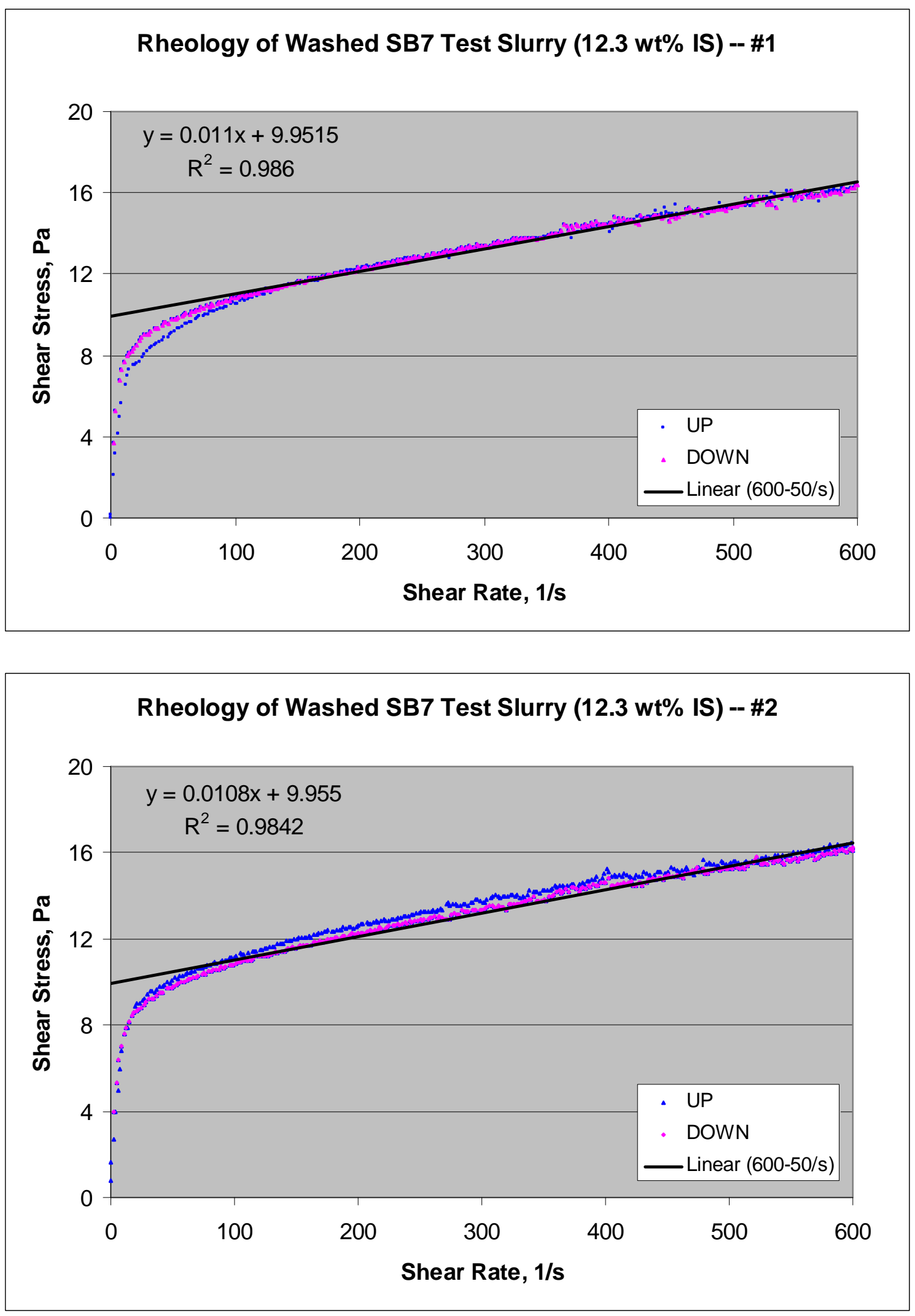


\section{Distribution:}

B. N. Attaway, 773-A

C. J. Bannochie, 773-42A

A. B. Barnes, 999-W

M. H. Beasley, 773-A

N. E. Bibler, 773-A

J. M. Bricker, 704-27S

D. R. Burckhalter, 773-A

D. A. Crowley, 773-43A

T. L. Fellinger, 704-26S

A. I. Fernandez, 999-W

S. D. Fink, 773-A

R. H. Galloway, 773-A

B. J. Giddings, 786-5A

J. M. Gillam, 766-H

B. A. Hamm, 766-H

E. K. Hansen, 999-W

C. C. Herman, 999-W

E. W. Holtzscheiter, 704-15S

S. J. Howard, 773-A

J. F. Iaukea, 704-30S

M. L. Jenkins, 773-A

L. C. Johnson, 773-A
M. A. Jones, 773-A

D. P. Lambert, 999-W

M. T. Keefer, 766-H

D. C. Koopman, 999-W

S. L. Marra, 773-A

J. B. Mixon, 773-A

J. E. Occhipinti, 704-S

J. M. Pareizs, 773-A

D. K. Peeler, 999-W

F. M. Pennebaker, 773-42A

H. M. Pittman, 704-27S

J. W. Ray, 704-S

S. H. Reboul, 773-A

H. B. Shah, 766-H

D. C. Sherburne, 704-S

A. V. Staub, 704-27S

M. E. Stone, 999-W

R. C. Sullivan, 773-A

D. J. Wheeler, 773-A

K. M. White, 773-A

B. J. Wiedenman, 773-A

A. W. Wiggins, 704-60H 